\title{
Judicially Initiated Prosecution: A Means of Preventing Continuing Victimization in the Event of Prosecutorial Inaction
}

This Comment proposes the use of court-appointed prosecutors to represent the interests of crime victims who are vulnerable to revictimization because the public prosecutor has refused to charge the alleged offender despite having probable cause. The Comment notes that the American criminal justice system currently vests the public attorney with exclusive discretion over the initiation of criminal proceedings and denies the crime victim any formal role in the prosecution of a criminal suspect. Though justified in most cases by values of procedural fairness and administrative efficiency, this configuration denies a certain class of victims the protection of the laws. Victims of certain types of crimes, such as spousal abuse, are often subject to continued victimization when the public prosecutor fails to charge the responsible party and alternative deterrent remedies are either unavailable or inadequate. This Comment argues that a victim should have recourse to judicial review of a public attorney's negative charging decision if that decision leaves the victim vulnerable to likely revictimization. The Author proposes a procedure through which courts may initiate criminal proceedings where a victim can demonstrate that prosecution is necessary to deter the suspected offender from continuing to persecute him. Such a procedure will provide much needed protection to this class of victims, in accordance with constitutional principles and sound public policy values.

\section{INTRODUCTION}

A criminal act injures both the victim of the crime and the commonwealth in general. The victim suffers the direct consequences of the offense, and the commonwealth suffers the violation of its laws. Under state and federal practice, however, only the commonwealth can prosecute the offender for his or her criminal action. ${ }^{1}$ A crime victim has no

1. See, e.g., Cardenas, The Crime Victim in the Prosecutorial Process, 9 HaRv. J.L. \& PuB. PoL'y 357, $374 \mathrm{n} .85$ (1986). Most state courts require public control of criminal prosecutions and do not permit a privately retained attorney to pursue a criminal prosecution unless the public prosecutor has given approval. Note, Private Prosecutors in Criminal Contempt Actions Under Rule 42(b) of the Federal Rules of Criminal Procedure, 54 FordhaM L. REV. 1141, 1154-55 (1986). The federal courts adhere to the same system. United States v. Bryson, 434 F. Supp. 986, 988 (W.D. Okla. 1977) ("The prosecution of criminal actions in the federal courts is a matter solely within the discretion of the Attorney General of the United States and duly authorized United States 


\section{legally recognized right to initiate criminal proceedings. ${ }^{2}$}

The exclusive allocation of prosecutorial power to the state reflects a fundamental conception of criminal justice - that crimes are offenses, not against the individual victinu, but against the public law and the cominumity. ${ }^{3}$ Since the public is considered the aggrieved party, its representative, ${ }^{4}$ and not the victini's private counsel, initiates and conducts the prosecution. Moreover, the putative objectives of criminal prosecution and conviction-deterrence, rehabilitation, and retribution ${ }^{5}$-are designed to achieve social goals; they are not directly linked to the cognizable interests of the individual crime victin. ${ }^{6}$

In situations where a crime victinu is likely to be revictinized by an offender, however, the victim's individual interest coincides with the general social goal of criminal deterrence. Criminal sanctions provide both "general deterrence," by discouraging potential offenders from violating the law, ${ }^{7}$ and "specific deterrence," by dissuading the criminal froin con-

Attorneys."); see also Powell v. Katzenbach, 359 F.2d 234 (D.C. Cir. 1965) (mandamus shall not control the Attorney General's discretion to prosecute), cert. denied, 384 U.S. 906 (1966).

2. The state now asserts a monopolistic power in the initiation and management of criminal proceedings ... criminal proceedings involve only two official parties: the state, as represented by the public prosecutor, and the defendant. The crime victim, who has suffered physical or financial loss, has no rights or role in the criminal process, other than as a witness.

Cardenas, supra note 1 , at 388.

3. This notion is a relatively recent one. Under early Anglo-American common law, criminal prosecutions proceeded for the bencfit of the victim, and private prosecution was the norm. As the conceptual distinction between crime and tort developed under common law, howevcr, the focus of criminal prosecution shifted from the redress of personal wrongs to the promotion of public interests: deterrence of crime, punishment and rehabilitation of criminals, and the pursuit of justicc. Cardenas, supra note 1, at 387-88; see also Standards Relating to the Prosecution FUnCTION \& THE DEFENSE FUNCTION $\$ 2.1$ commentary at 49 (Tent. Draft 1970)("The idea that the criminal law, unlike other branches of the law such as contract and property, is designed to vindicate public rather than private interests is now firmly established."); H. ABADINSKY, DISCRETIONARY JUSTICE 62-63 (1984) ("the American prosecutor has inherited the power of private prosecution").

The public control of prosecution developed out of practical concerns as well. For one, it places prosecutorial discretion in the hands of a public official whose decisions are ideally based on "rational" criteria, such as sufficiency of the evidence and the public importance of the case, rather than the emotional and the personal motives of a private victim. See, e.g., Young v. United States ex rel. Vuitton et Fils S.A., 107 S. Ct. 2124, $2139-40$ (1987); Note, supra note 1, at $1149 \&$ n.38. It also better assures that trained and experienced counsel will conduct the prosecution. See infra text accompanying note 135 . Moreover, public prosecution promotes uniformity in the interpretation and enforcement of the law. Cardenas, supra note 1, at 371.

4. This Comment uses various terms interchangeably to identify the public prosecutor: district attorney, public attorney, or government attorney. The terms all refer to the prosecutor who is employed directly and exclusively by the state. Also, since the Comment discusses prosecution in general, without distinguishing between jurisdictions, these terms apply to both federal and state prosecutors.

5. See generally A. Blumberg, CRIMINAL JUSTICE $316-38$ (2d ed. 1979).

6. See Linda R.S. v. Richard D., 410 U.S. 614,619 (1973) ("a private citizen lacks a judicially cognizable interest in the prosecution or nonprosecution of another").

7. General deterrence results because the criminal sanction "maximiz[es] the perceived costs 
tinuing to commit crimes. ${ }^{8}$ When a crime victim is likely to suffer repeated injury from an offender, the victim of a crime has a valid personal interest in specific deterrence; that is, $\mathrm{m}$ preventing his or her revictimization. ${ }^{9}$ This interest is particularly acute when the suspect is apprehended for one offense in a continuing series of illegal acts directed at the victim.

Generally, victims can deter feared revictimization by pursuing a civil or equitable remedy. Civil damages, though calculated primarily to coinpensate the victim for injury from the initial violation, also discourage the offender from repeating the criminal act. ${ }^{10}$ An injunctive court order directly commands the offender to refrain from further violations of the victim's interests. When equitable or civil measures prove inadequate to deter the offender, ${ }^{11}$ however, the only legal means of preventing future victimization is criminal prosecution. This Coinment argues that individuals susceptible to revictimization who lack adequate civil and equitable relief have a valid interest in the prosecution. ${ }^{12}$

Although protection of a victimi's interest in preventing revictimization hinges on the government prosecutor's charging decision, current law places the government under no duty to protect this interest through criminal prosecution. Since the government has monopoly control over the machinery of law enforcement, the district attorney generally has complete, virtually unreviewable ${ }^{13}$ discretion over whether to prosecute a

to potential criminals and thereby reduc[es] their willimgness to engage in criminal behavior." Barnett \& Hagel, Assessing the Criminal: Restitution, Retribution and the Legal Process, in Assessing the CRiminal 3 (R. Barnett \& J. Hagel eds. 1977).

8. The concept of special deterrence places emphasis on the particular offender by imposing punishment (usually imprisonment) for a period of time sufficient to increase the offender's perception of the threat of punishment as being likely to occur. In this way, it is expected that the probability of future criminal behavior for that individual is diminished, if not eliminated (emphasis omitted).

A. BLUMBERG, supra note 5 , at 323 .

9. Deterrence is not the only prosecutorial objective of interest to the victim. Incapacitating the offender through imprisonment effectively prevents revictimization, at least for the period of incarceration. See id. at 327 (characterizing incapacitation as a form of preventive deterrence). For purposes of this Comment, the term "deterrence" subsumes both the classic instructive function of deterrence and the direct preventive function of incapacitation.

10. See infra text accompanying note 37 .

11. For a discussion of the inadequacy of civil and equitable remedies, sec infra text accompanying notes 37-62.

12. Some victims' rights advocates would argue that a victim has a right to government protection through prosecution, equivalent to the general right to protection enjoyed by all citizens. Richard Aynes argues that "[i]t should be axiomatic that everyone has a 'right' not to be victimized." Aynes, Constitutional Considerations: Government Responsibility and the Right Not to be a Victim, 11 Pepperdine L. Rev. 63, 65 (1984). He derives support for the existence of the right to government protection froin criminal mjury in statutory and decisional law, and in the great texts of American history, including the Constitution, the Declaration of Independence, and the Virginia Bill of Rights. Id. at 75-84.

13. Courts will review a negative charging decision only for the possibility of abuse of discretion. See A. Blumberg, supra note 5, at 124 ("prosecutorial discretion is generally subject to 
particular case.

The government's monopoly over prosecutorial resources, however, carries with it the responsibility for protecting citizens from crime. Under social contract theory, government is founded on an implicit agreement by the members of society to surrender to the state their natural right to protect themselves in return for an assurance that the government will protect them. ${ }^{14}$ Consequently, the government may maintain its monopoly over law enforcement and prosecution only so long as it fulfills its "separate and imdependent duty to protect those under its jurisdiction from becolming the victims of crime." 15

Although courts have been reluctant to liold the government to an actionable general duty of protection in tort cases, ${ }^{16}$ they have indicated that the government's responsibility to protect a citizen increases once it knows that a specific citizen is in danger of likely harm. ${ }^{17}$ Similarly, when a crime victim demonstrates to the prosecutor that criminal prosecution is the only way to prevent a likely revictimization, this Comment argues, the prosecutor should be under a special duty to protect that victim by filing criminal charges. If the prosecutor refuses, the government violates its duty to defend the victim's correlative interest in protection

review because of bad faith, fraud, or illegality, but in criminal cases such review will be limited to whether discretion has been abused, and ... except for the inost outrageous instances a prosecutor cannot be compelled to prosecute").

14. Under this Lockean construct, "[t]he government's duty to protect [is] the quid pro quo for a citizen's duty of allegiance." Aynes, supra note 12, at 75. To illustrate this implicit agreement between citizens and state, Professor Aynes draws an analogy to the prototypical television Western in which "the act of giving up one's guns at the city limits is predicated upon the assurance that the town marshall will offer protection against unprovoked violence." Id. at 88; see also Hudson, The Crime Victim and the Criminal Justice System: Time for a Change, 12 PEPPERDINE L. REV. 23, 31 (1984) (explaining "the natural law idea that the government's monopoly on the use of force carries with it the duty to protect its citizens from attack and theft'). See gencrally J. LOCKE, SECOND Treatise of Government 4-11 (T. Reardon ed. 1952) (stating that citizens surrender to the government the right to enforce the law of nature while retaining all other rights).

15. Aynes, supra note 12 , at 66 .

16. In tort actions against police officers for negligent failure to protect a citizen from harm, courts often deny recovery either on immuırity grounds, see Jamison v. City of Chicago, 48 Ill. App. 3d 567, 363 N.E.2d 87 (1977) (state government immunity statute precludes recovery in wrongful death action for failure of Chicago police to arrest person who subsequently murdered plaintiff's decedent), or on the theory that "a government and its agents are under no general duty to provide public services, such as police protection, to any particular individual citizen." Warren v. District of Columbia, 444 A.2d 1, 3 (D.C. Ct. App. 1981) (quoting the inemorandum opinion of the trial court's denial of recovery in action against police for negligent failure to respond to distress call by plaintiffs who were subsequently kidnapped, raped, and robbed (reprinted id. at 4)).

17. In tort cases against the police, courts liave examined whetler the police were aware of the plaintiff's danger in order to establish the police department's duty to protect the injured plaintiff. See, e.g., Green v. Francis, 705 F.2d 846, 849 (6th Cir. 1983) (police liable to civil rights plaintiffs in part for failure to respond to plaintiff' pleas for lielp when their house was being barraged with gunfire); Schuster v. City of New York, 5 N.Y.2d 75, 80-81, 154 N.E.2d 534, 537, 180 N.Y.S.2d 265, 269 (1958) (the public "owes a special duty to use reasonable care for the protection of [police informers] once it reasonably appears that they are in danger due to their collaboration."). 
from criminal injury, thereby losing its valid claim to a monopoly over law enforcement.

This Comment argues that in those cases where the state refuses to prosecute such charges, an exception to the public prosecutor's monopoly over the charging process is justified, because the state has failed to represent the victim's valid interest. Accordingly, victims who reasonably fear continuing victimization should have recourse to a remedy that overrides the public prosecutor's negative charging decision.

This Comment proposes a procedure that permits a crime victim to petition the court for a judicially initiated prosecution if the public prosecutor refuses to file a charge. ${ }^{18}$ The petitioner must present evidence that the cliarge is justifiable and demonstrate tliat furtlier injury is likely unless criminal prosecution is brouglit to deter the offender from contm-

18. Such participation by the victim is consistent with the recent recognition by the courts, legislatures, and academic commentators that crime victims have a legitimate interest in the disposition of the governmeut's case against the alleged offender. As of 1984, 14 states had adopted a Victims' Bill of Rights which grants the crime victim a right to information, notice, and participation in the criminal proceedings. Kelly, Victims' Perceptions of Criminal Justice, 11 PEPPERDINE L. REV. 15, 21-22 (1984). A number of states permit the imtroduction of victim impact statements at the sentencing of certain crimes. A. KARMEN, CR1ME V1CTIMS 230-31 (1984). See Hudsou, supra note 14, at $51 \mathrm{nn}$. 136-37, for a hist of states that have adopted or were cousidering adopting victim impact statement laws as of May 1983. Moreover, the practice of requiring the offender to pay restitution to the victim is experieucing a revival in this country. See A. KARMEN, supra, at 180; Gittler, Expanding the Role of the Victim in a Criminal Action: An Overview of Issues and Problems, 11 PePperdine L. REv. 117, 136 (1984) (because of the "rediscovery of restitutiou within the criminal justice system ... [a]lmost all states and the federal government have statutes dealing with restitution."); see also Jolmson, Crime Victims Getting a Day, and a Say, in Court, N.Y. Times, Apr. 1, 1988, at B7, col. 3 (summarizing recent legislation permitting victims a role in the proseeution of criminals).

Coincident with these statutory changes has been the development of "victimology," the academic study of the victim's role and interests in the criminal justice system. A. KARMEN, supra, at 23 . In recent years numerous commentators have argued that a crime victim should have the right to participate directly in the prosecution of the alleged perpetrator. These proposals vary from permitting victims to pursue a restitutionary interest to advocating fully private prosecutions of criminal charges. See, e.g., Barnett \& Hagel, supra note 7, at 25-30 (describing a restitutionary theory of justice in which the parties to a criminal action are the victim and the defendant); Cardenas, supra note 1, at 393 (proposing that a crime victim be allowed to appeal a public prosecutor's negative charging decisions to a magistrate); Gittler, supra, at 159 (explaining that the public prosecutor's uucontrolled discretionary power raises the possibility of abuse of discretion and speculating that "it is conceivable that victim-initiated prosecution could provide a useful and needed cheek on prosecutorial charging discretiou"); Goldstem, Defining the Role of the Victim in Criminal Prosecution, 52 Miss. L.J. 515, 557-61 (1982) (the victim should be authorized to participate as a party in criminal proceedings, including hearings on dismissals, charge reductions, guilty pleas, restitution, and sentenciug); Note, Private Challenges to Prosecutorial Inaction: A Model Declaratory Judgment Statute, 97 YALE L.J. 488 (1988) (proposing statute that authorizes courts to review a negative charging decision and to issue an unenforceable, but potentially influential, declaratory judgunent that the public prosecutor has abused his or her discretion); Commeut, Private Prosecution: A Remedy for District Attorneys' Unwarranted Inaction, 65 YALE L.J. 209, 229-34 (1955) (proposing a private ineans of retribution by which courts may appoint the victim's private counsel to proseeute the criminal charge upon a determination that the district attorney improperly refused to file charges). 
uing the illegal conduct. Upon this showing, a trial court would appoint a prosecuting attorney and initiate criminal proceedings. ${ }^{19}$

This procedure for appointing a prosecutor should be implemented whenever the government's decision not to file a justifiable criminal charge leaves the victim vulnerable to revictimization. ${ }^{20}$ The crime of trademark infringement, for example, often raises this scenario. Trademark infringers typically produce low-quality goods, label them with imitations of a well-known manufacturer's trademark, and pass them into trade as genuine products of the manufacturer. ${ }^{21}$ This activity violates federal law $\mathrm{law}^{22}$ and may constitute a huge sales loss to the owner of the trademark. ${ }^{23}$ Consequently, manufacturers are vitally concerned with deterring future infringement.

19. Note that the petitioning procedure would be available only to persons who have already been victimized by the offender. This Comment maintains that non-victims claiming a likelihood of future victimization by a particular offender would not have standing to invoke this procedure.

Traditional standing doctriue requires that a plaintiff show "an injury to himself that is likely to be redressed by a favorable decision." Simon v. Eastern Ky. Welfare Rights Org., 426 U.S. 26, 38 (1976). The requisite harm can consist of either "threatened or actual injury resulting from the putatively illegal action." Linda R.S. v. Richard D., 410 U.S. 614, 617 (1973).

Although the non-victim has suffered no actual injury, he or she might claim standing in a prosecution on the grounds that the suspect is likely to victimize him or her in the future unless deterred by proseeution. Absent a demonstrable course of persecution by the offender, however, it is unlikely that the non-victim can show "the existence of any [tlireatened] injury . . . of sufficient immediacy and ripeness to warrant judicial intervention." Warth v. Seldin, 422 U.S. 490, 516 (1975). As such, the non-victim has no more interest in the prosecution of the offender than any member of the general public. It is well established that "concerned bystanders" without the requisite interest have no standing to invoke the judicial process to enforce the laws. Unitcd States v. Students Challenging Regulatory Agency Procedures, 412 U.S. 669, 687 (1973).

Existing private statutory causes of action against certain criminal offenders similarly deny standing to parties who have not been injured by the alleged criminal violation. The private civil causes of action under the federal antitrust statutes and the Racketeer Influenced and Corrupt Organizations Act (RICO), 18 U.S.C. $\$ \S 1961-1968$ (1982), allow parties to recover treble damages from violators of these statutes. These provisions are analogous to this Coinment's proposal in that they permit private parties the means to enforce criminal laws, and may result in the imposition of punishment beyond mere coinpensatory civil damages. Both statutes require the traditional "injury in fact" to establish standing in a private action. 15 U.S.C. $\S 15 ; 18$ U.S.C. $\S 1964$ (c) (1982) (any person "injured in lis business or property" by a violation of the antitrust laws or RICO, respectively, may sue therefore and recover treble damages and the costs of the suit). This Comment similarly adopts the injury-in-fact requirement. For a discussion of the victim's standing to use this proposed procedure, see infra text accompanying notes 76-82.

20. The helplessness of the crime viction iu this situation illustrates the general disregard for victims' interests in our systein. The exclusiou of victins from a role in tlie prosecutorial process has led one autlior to conclude that "[t]lie victins of crime are truly the forgotten people in the American criminal justice system." Gittler, supra note 18, at 117; see also A. KARMEN, supra note 18, at 3; Cardenas, supra note 1 , at 384; Goldstein, supra note 18, at 518-20.

21. See Kneale, Makers of Designer Goods Starting to Crack Down on Counterfeiting, Wall St. J., June 28, 1982, at 17, col. 4 (describing the extent of trademark counterfeiting).

22. Trademark Counterfeiting Act of 1984,15 U.S.C. $\$ \S 1116-1118$ (Supp. IV 1986) and 18 U.S.C. § 2320 (Supp. IV 1986).

23. Calvin Klein, for example, estimates that trademark counterfeiting costs the designer about $\$ 20$ million a year in lost revenue. Kneale, supra note 21 , at 17, col. 6 . 
When a manufacturer discovers that a certain party is copying its trademark, it has several legal options. It can urge the United States Attorney to prosecute the infringer, in order to derive the specific deterrence benefits of criminal sanctions. If the government refuses to prosecute, ${ }^{24}$ the manufacturer must rely entirely on civil and equitable remedies to deter future infringement. Civil damages, however, may be ineffective if the infringer is insolvent, ${ }^{25}$ or if all attachable assets are outside of the country. ${ }^{26}$ Likewise, an injunctive order may have little effect against such illegal operations. ${ }^{27}$ Under these circumstances the trademark owner is foreclosed from all available deterrence and vulnerable to contmued trademark infringement.

Similarly, abused spouses are frequently left without a means of preventing contimued abuse. Prosecutors regularly refuse to charge husbands with domestic violence, choosing not to intervene in domestic disputes. ${ }^{28}$ In fact, one study found that $92 \%$ of the battered women cases in Detroit were never prosecuted. ${ }^{29}$ Consequently, the battered wife typically resorts to the courts for a civil injunction restraining the husband from future abuse. Because these orders are often ineffective, ${ }^{30}$ however, the prosecutor's inaction effectively leaves a battered wife vulnerable to continued abuse. ${ }^{31}$

The same potential for reoffending arises in the context of wlitecollar crime. Much wlnte-collar crime goes unprosecuted due to both sociological and practical considerations. ${ }^{32}$ For one, suspects of business crime tend to receive leinent treatment from prosecuting attorneys, who

24. Prior to the enactment of the Trademark Counterfeiting Act, the primary criminal remedy against these counterfeiters was a criminal contempt action for violating existing court orders enjoining this activity. Although manufacturers requested that the United States Attorney's Office prosecute these cases, it generally refused, presumably because it lacked the resources to handle the numerous complaints. See infra text accompanying note 56.

25. See infra text accompanying note 39 .

26. The factories that produce counterfeit goods are often located in foreign countries. In Young v. United States ex rel. Vuitton et Fils S.A., 107 S. Ct. 2124 (1987), for example, the factory that produced the counterfeit Vuitton handbags was located in Haiti. Id. at 2129.

27. See infra text accompanying notes 40-62.

28. See, eg., Eisenberg \& Micklow, The Assaulted Wife: 'Catch 22' Revisited, 3 WoMEN's RTs. L. REP. 138, 145-46 (1977) (prosecutors are often unwilling to prosecute charges arising out of "family squabbles"); Gates, Victims of Rape and Wife Abuse, in WOMEN IN THE COURTS 176, 195 (1978) ("Prosecutors are faulted ... for denyimg battered women access to the criminal courts. Only a fraction of the requests women make to prosecutors for arrest warrants are granted.").

29. J. Fleming, Stopping Wife Abuse 199-200 (1979) (citing J. Bannon, LAW Enforcement Problems with INTRA-Family Violence (study presented to the A.B.A. Convention, Aug. 12, 1974)).

30. See Eisenberg \& Micklow, supra note 28, at 153-55.

31. See generally Truninger, Marital Violence: The Legal Solutions, 23 Hastings L.J. 259 (1971) (criticizing the ineffectiveness of the legal system in cases of marital violence).

32. See Volgyes, The Investigation, Prosecution, and Prevention of Computer Crime: A State-ofthe-Art Review, 2 COMPUTER L.J. 385, 388 (Spring 1980) (citing the low probability of conviction faced by white-collar criminals). 
often share the same social class and economic background as the whitecollar crimmal. ${ }^{33}$ Moreover, elected prosecutors are often reluctant to risk losing the financial and political support of the business community by prosecuting local businessmen. ${ }^{34}$ As a result, the victim of a whitecollar violation often cannot prevent its recurrence unless the offender is subject to deterrence through civil or equitable actions.

In all the preceding situations, the victim must rely on the criminal justice system to deter the offender from repeated criminal conduct. If the public prosecutor refuses to file charges, the victim is left vulnerable to revictimization. ${ }^{35}$ This Comment maintains that such a victim should be afforded a deterrent remedy through court-initiated prosecution. By proposing a particular court-appointment procedure that jurisdictions may adopt by legislation, ${ }^{36}$ and analyzing its practical and constitutional imphications, this Comment seeks to demonstrate that judicially initiated prosecution can provide this victim a realistic renedy for prosecutorial inaction.

Part I of this Comment demonstrates that the criminal, civil, and equitable measures currently available to crime victims are sometines madequate to prevent revictimization. Part II offers a proposal to authorize the appointment of independent prosecutors and discusses its practical dynamics. Part III demonstrates that this proposal is constitutional under due process and separation of powers analyses. The Comment concludes that a legislature's adoption of this or a sinilar proposal will enhance the protection of crime victims in accordance with constitutional limitations and important policy values.

33. See G. GeIs, ON WhITE-Collar CRIME 56 (1982) (describing the enforcement problems caused by "the class congruence between the white-collar offender and the persons who pass official judgment on him"). $C f$. Walsh and Schram, The Victim of White-Collar Crime: Accuser or Accused?, in White-Collar CRIME: Theory and Research 32, 35 (1980) ("[T] he power and status of the white-collar offender[] are generally believed to contribute to leniency in white-collar crime sanctioning practices.").

34. G. GEIS, supra note 33 , at 56.

35. Note that, in all types of criminal cases, prosecutorial bias may deny crime victims muchneeded protection from revictimization. A district attorney may refuse to charge an offender out of an improper motive unrelated to the merits of the case. See infra notes 64-71 and accompanying text. Because of the virtually unlimited discretion proseeutors enjoy, such conduct is difficult to curb. See infra notes 143-45 and accompanying text. A racially biased prosecutor, for example, can inject personal prejudices into all the discretionary stages of the prosecutorial process. See, e.g., Patermoster, Race of Victim and Location of Crime: The Decision to Seek the Death Penalty in South Carolina, 74 J. CRIM. L. \& CRIMINologY 754, 767-85 (1983) (a study found that the race of victim and killer has a large influence on the prosecutor's decision to seek the death penalty in murder cases in South Carolina). This prejudice is particularly apparent when the prosecutor refuses to file a charge because of the race of the victim. See Comment, Prosecutorial Discretion in the Initiation of Criminal Complaints, 42 S. CAL. L. REv. 519, 528 (1969) (explaining that minority groups arc denied equal protection of the laws when prosecutors fail to prosecute offenses against membcrs of that group); infra note 69 and accompanying text.

36. See infra note 73. 


\section{The Need for Court-Initiated Prosecution}

The prevailing legal system provides many crime victims with no effective legal means of preventimg repeated victimization. A victim may have evidence linking a suspect to the crime, and may know, from the suspect's prior course of conduct, that the suspect is likely to victimize him or her again. That victim will naturally wish to prevent future injury. The current legal system offers that victim an array of responses: the victim may sue for civil damages, seek equitable imjunctions, or press criminal charges. Although these measures may deter some suspects from continuing to persecute the victim, the measures are often ineffective for reasons discussed below.

\section{A. Civil Damages}

Civil damages provide an incentive for a criminal to refrain from repeating his offense. For example, a substantial monetary judgment for tradennark infringement will certainly make the infringer think twice before resuining any counterfeiting. This deterrent effect may be enhanced by further punitive damages, which are frequently imposed where the underlying tort is also a criminal offense. ${ }^{37}$

Nevertheless, civil damages may fail to effectively deter further offenses against the same victim. First, damages will often have no effect on the amoral calculator who deterinines that the potential gam from continued criminal activity outweighs any potential penalties. In a recent trademark infringement case, for example, the defendant continued to copy a coinpany's trademark even though the company had secured a \$100,000 judgment agamst him for an earlier trademark violation. ${ }^{38}$ Moreover, although the threat of punitive damages may provide further deterrence, punitive damages are not guaranteed; the factfinder may deem the offense unworthy of punishment beyond actual damages. Finally, the assessment of damages will have absolutely no deterrent effect on insolvent criminal offenders. Since a great number of criminals are judgment-proof, civil remedies frequently may not deter these criminals from inflicting future harm upon their victims. ${ }^{39}$

37. See Schwartz, Deterrence and Punishment in the Common Law of Punitive Damages: A Comment, 56 S. CAL. L. REv. 133, 143-45 (1982) (explaining the penal theory behind punitive damages and their application in cases where the tortious conduct is also criminal).

38. Young v. United States ex rel. Vuitton et Fils S.A., 107 S. Ct. 2124 (1987). The trial court found the defendant guilty of criminal contempt for violating a court order enjoining continued trademark violation issued in conjunction with the damages award. Id. at 2128-29.

39. See A. KARMEN, supra note 18, at 193 (street criminals "are often 'judgment-proof'broke or hard to collect from without incurring great expense because they have spent or hidden the spoils of their crime"); Comment, The Outmoded Concept of Private Prosecution, 25 AM. U.L. REV. 


\section{B. Injunctions}

A crime victim may prevent recurring injury by securing a court order enjoining the perpetrator from further violations. He or she can obtain this injunction by showing two eleinents: (1) that there is a "reasonable likelihood of violations of law in the future" ${ }^{30}$ causing the victim irreparable harm; and (2) that no adequate remedy or relief exists at law to protect that victim's interests. ${ }^{41}$

Injunctions are deterrent by defintion; they order a person to do or to refrain from doing a certain act. Violation of the court order subjects the enjomed party to a charge of contempt of court. For various reasons, however, court-ordered imjunctions and the attendant threat of enforcement through contempt proceedings are often inadequate to deter the enjoined party from contmumg the prohibited activity.

First, an mjunction lacks intrinsic deterrent force. Unlike a criminal sentence, an mjunction merely threatens criminal or civil penalties in the event of its violation. The charge resulting from the violation of a court order-contempt of court-does not arise until after the victim has already suffered the feared injury. Thus, when a victim secures an injunction agamst criminal conduct after an mitial offense, that victim caimot count on deterrent sanctions until she has suffered a second offense.

Second, the threat of contempt sanctions provides little additional deterrence to a person contemplating the coinmission of a crime, since that person already faces the possibility of consequent criminal penalties. This is especially true when a crime victim seeks to enjom the perpetrator from repeating a crime. If the threat of regular criminal sanctions failed to deter the offender from committing the first violation, there is no reason to think that the additional possibility of contempt sanctions will deter a second offense. ${ }^{42}$

Finally, the measures available to enforce a judgment of contempt possess various weaknesses that undermine their deterrent value. Contempt proceedings come in two forns, civil and criminal, which are distinguished by their differing purposes and sanctions. ${ }^{43}$ Neither measure,

754, 789 (1976) (noting that criminal defendants are usually judgment-proof); Comment, supra note 18 , at 228 ("the criminal is almost always judgment-proof").

40. Bowles v. Minish, 56 F. Supp. 153, 155 (S.D. Ala. 1944).

41. E.g., Rondeau v. Mosinee Paper Corp., 422 U.S. 49, 57 (1975); Humble Oil \& Refining Co. v. Harang, 262 F. Supp. 39, 42 (E.D. La. 1966).

42. A similar situation arose in Young v. United States ex rel. Vuitton et Fils S.A., 107 S. Ct. 2124, 2128-29 (1987). In that case the defendant faced criminal contempt charges because he had persisted in imitating another company's trademark even after a court had assessed civil damages for previous violations and enjoined further infringement.

43. See generally Dobbs, Contempt of Court: A Survey, 56 CoRnell L. REv. 183 (1971) 
however, provides rehably effective deterrence against continued criminal activity.

\section{Civil Contempt}

Civil contempt proceedings are "instituted to preserve and enforce the rights of private parties" by enforcing court orders granted in their favor. ${ }^{44}$ Civil contempt sanctions are remedial and coercive, intended not to pumish but to compel comphance with the court order..$^{45}$ A prison sentence for conteinpt, for example, will last only until the defendant complies with the violated court order. ${ }^{46}$

The coercive sanction for civil contempt often effectively induces compliance with a court order that mandates an affirmative act, such as testifying at a trial. However, a coercive sanction cannot force compliance with a prohibitory order, like an imjunction agamst a party's contimued trademark infringement. ${ }^{47}$ If the trademark infringer is imprisoned, for exainple, he or she cannot possibly demonstrate that, if released, he or she would refrain from future trademark violations. ${ }^{48}$ Fines have the same shortcoming; they are necessarily determinate. While they may be used to compensate the injured party, ${ }^{49}$ civil fines cannot effectively coerce the contemnor into refraining from further violations.

Because a civil contempt sanction cannot coerce compliance witlı a negative imjunction, the deterrent effect of the sanction depends largely on the degree to which a defendant respects the court's authority. In many cases, therefore, it does not provide an effective remedy for a party that fears revictinnization.

\section{Criminal Contempt}

Criminal contempt proceedings serve "to preserve the power and vindicate the dignity of the courts and to punisl for disobedience of their

(explaining the law of contempt and suggesting areas suitable for legislative restructuring of the contempt power).

44. Bessette v. W.B. Conkey Co., 194 U.S. 324, 328 (1904) (quoting In re Nevitt, 117 F. 448, 458 (8th Cir. 1902)).

45. Examples of court orders enforced by civil contempt actions include orders to testify and civil damages awards. Once the witness testifies or the defendant pays the damages, the contempt sanctions are removed.

46. See Rakoff, Private Prosecutors, 194 N.Y.L.J. No. 94, Nov. 14, 1985, at 4, col. 1.

47. Courts use various methods to induce compliance with prohibitory orders through coercive sanctions. Some judges will set a sentence for the contempt violation and free the contemnor upon his expression of willingness to comply with the order in the future. Dobbs, supra note 43, at 269. Others will set suspended sentences to be applied only if the contemnor repeats the contempt. Id. at 268.

48. See id. at 269 ("where the injunctive order is prohibitory in nature . . . there is no way the contemnor can, while in jail, demonstrate his willingness to avoid future violations").

49. Id. at 275 . 
orders."so The objective of the prosecution is to punish the violator, not to force comphance with the violated court decree. ${ }^{51}$ The sanctions, therefore, are determmate and do not cease upon compliance.

The crime victim who wishes to prevent further injury could secure an injunction in the hope that the prospect of criminal contempt charges will dissuade the perpetrator from repeating the crime. The threat of criminal contempt charges, however, is often ineffective to deter revictimization. First, criminal contempt prosecutions are not a guaranteed consequence of an mjunction violation. The courts have complete discretion over whether to bring contempt charges and are generally unwilling to bring them for the protection of individual litigants. Criminal contempt prosecutions, as the Umited States Supreme Court has explained, "are designed to serve the limited purpose of vindicating the authority of the court."52

Criminal contempt sanctions may also be ineffective because often no prosecutor is available and willing to prosecute bona fide contempt violations. When a violation occurs in the presence of the court, as when a witness refuses to testify, the judge may punish the contemnor summarily, without the usual adversary criminal procedures. ${ }^{53}$ But, when the violation occurs outside of the courtroom, as when a tradeinark infringer violates an injunction against continued tradeinark counterfeiting, the alleged contemnor must be fornally prosecuted and proven guilty beyond a reasonable doubt in adversary proceedings. ${ }^{54}$ Public prosecutors, however, often fail to prosecute these contempt cases because of their already overwhelming caseloads. ${ }^{55}$ In fact, violations of injunctions against trademark infringement rarely result in contempt charges. Manufacturers have " "tried to get U.S. attorneys to take these cases and unfortunately they're not interested." "56

50. Bessette v. W.B. Conkey Co., 194 U.S. 324, 328 (quoting In re Nevitt, 117 F. 448, 458 (8th Cir. 1902)).

51. See Rakoff, supra note 46 , at 4 , col. 2.

52. Young v. United States ex rel. Vuitton et Fils S.A., 107 S. Ct. 2124, 2133 (1987). Cf. Commonwealth v. Stratton Finance Co., 310 Mass. 469, 38 N.E.2d 640 (1941), in which the court held that a criminal statute could not be enforced by injunction because that practice would deprive the defendant of a jury trial, substitute a punishment chosen by a judge for the definite penalties fixed by the legislature, and potentially result in arbitrary exercises of power and "government by injunction." Id. at 474,38 N.E.2d at 643 .

53. See Young, 107 S. Ct. at 2133; see also Rakoff, supra note 46, at 4, col. 1.

54. Young, 107 S. Ct. at 2133; see also Dobbs, supra note 43, at 222-23; Note, supra note 1, at 1142.

55. See, e.g., United States ex rel. Vuitton et Fils S.A. v. Karen Bags, 592 F. Supp. 734, 744 (S.D.N.Y. 1984) ("Realistically . . . aggrieved plaintiffs . . cannot depend on the United States Attorney's Office to enforce the court's mandates ....”), aff'd sub nom. United States ex rel. Vuitton et Fils S.A. v. Klayminc, 780 F.2d 179 (2d Cir. 1985), rev'd sub nom. Young v. United States ex rel. Vuitton et Fils S.A., 107 S. Ct. 2124 (1987).

56. Arthurs, Pioneering Methods Mark Firm's Attack on Bogus Goods, Legal Times, Oct. 28, 1985, at 28, col. 2 (quoting Milton Springut, an attorney who coordinates legal actions against 
To remedy the shortcomings of criminal contempt sanctions, the federal system provides a procedure under Federal Rule of Criminal Procedure 42(b) whereby the court can appoint a private attorney to prosecute criminal contempt proceedings regardless of the public attorney's refusal to prosecute. ${ }^{57}$ A recent Umited States Supreme Court decision has severely restricted this practice, however. In Young v. United States ex rel. Vuitton et Fils S.A., ${ }^{58}$ the Court invalidated the Second Circuit's practice of appointing the private counsel of the mjunction's beneficiary to prosecute the violation of that mjunction. The Court found that an unacceptable conflict of interest arises when counsel for a party with such direct private interest $m$ the litigation conducts the prosecution of the alleged contemnor. ${ }^{59}$

The Young prohibition greatly limits a court's ability to initiate prosecution under Rule 42(b). If the United States Attorney refuses to prosecute, as is not unconimon, ${ }^{60}$ the court is left with no one to prosecute the contempt. Moreover, lacking public funds to pay attorneys' fees, a court reakstically cannot appoint a disinterested private attorney. ${ }^{61}$ Consequently, Rule $42(\mathrm{~b})$ does not assure a crime victim a remedy

counterfeiters of Polo Merchandise). Apparently prosecutors choose to devote their resources to other charges that they perceive as more serious. See infra note 68 and accoripanying text.

57. While Rule 42(b) does not explicitly provide for this power of judicial appointment, courts have interpreted the rule's notice requirement to authorize it. The rule states that "notice shall be given orally by the judge in open court in the presence of the defendant or, on application of the United States Attorney or of an attorney appointed by the court for that purpose, by an order to show cause or an order of arrest." FED. R. CRIM. P. 42(b) (emphasis added). The United States Supreme Court has recognized that this interpretation "reflects the long-standing acknowledgement that the initiation of contempt proceedings to pumish disobedience to court orders is a part of the judicial function." Young, 107 S. Ct. at 2131 (1987); see also Umversal City Studios v. N.Y. Broadway Int'l Corp., 705 F.2d 94, 97 (2d Cir. 1983) (noting that the plain implication of the rule is that the proceedings are to be prosecuted either by a federal prosecutor or a specially designated private attorney); Musidor, B.V. v. Great American Screen, 658 F.2d 60, 65 (2d Cir. 1981) (stating that Rule 42 permits the appointment of private counsel), cert. denied, 455 U.S. 944 (1982).

58. 107 S. Ct. 2124 (1987).

59. The Court was concerned that this attorney, though acting on behalf of the state, might place the private client's interests before the goals of justice in conducting the prosecution. This conflict of interest creates "an appearancc of impropriety that diminishes faith in the fairness of the criminal justice system in general." Id. at 2139. Though a court can still appoint an attorney to prosecute contempt charges under Rule 42(b), it may no longer appoint the interested party's counsel to conduct the prosecution.

60. See supra note 55 and accompanying text.

61. The Young Court did not adequately deal with this practical problem, relegating it to a brief footnote. It cited to the Brief for the United States as Amicus Curiae, which maintains that the operating funds allocated to the Administrative Office for the United States Courts were adequate to flnance court-initiated contempt prosecution. $107 \mathrm{~S}$. Ct. at $2137 \mathrm{n} .17$. As the Brief for the United States as Respondent explains, however, the General Counsel of the Administrative Office has indicated that funds have historically been unavailable to pay private prosecutors and are unlikely to materialize in the future. Brief for the United States as Respondent at 23-24, Young (Nos. 85-1329 and 85-6207). See also Musidor, B.V. v. Great American Screen, 658 F.2d 60, 65 (2d Cir. 1981) ("There is no fund out of which to pay [disinterested] counsel . . . "), cert. denied, 455 U.S. 944 (1982). 
for the United States Attorney's decision not to prosecute the violation of an injunction.

Finally, even when a criminal contempt charge is pursued, the consequent penalty often provides very hittle deterrence. Many state statutes limit the sanctions available for criminal contenpt. ${ }^{62}$ Since these statutory sentences are often quite minimal, a conviction for criminal contempt may carry httle deterrent force if a contemnor is determined to persist in illegal activities.

\section{Criminal Prosecution}

When civil and equitable remedies prove inadequate to deter the perpetrator from repeating a crime, the crime victim's only remaining source of rehef is the criminal justice systein. Criminal prosecution, however, does not provide the victim with a foolproof means of deterring future injury, because quite simply, not all criminal offenses are prosecuted. Public prosecutors determine singlehandedly which cases to prosecute, ${ }^{63}$ and can refuse to prosecute a given case for virtually any reason.

Prosecutors frequently base their charging decisions on a niyriad of factors other than the merits of the case. ${ }^{64}$ The primary factor influencing a prosecutor's charging decision, aside from the merits of the case, ${ }^{65}$ is the availability of prosecutorial resources. ${ }^{66}$ State and federal prosecutors' offices operate under overwhelming caseloads, ${ }^{67}$ and they lack the inanpower and fiscal resources to prosecute every case. Consequently, they typically devote their scarce resources to more serious crimes and more readily ignore cliarges perceived as less serious. ${ }^{68}$ In addition, the

62. In several states the maximum sentence is only thirty days imprisonment plus a fine of $\$ 500$ or less. E.g., N.Y. Jud. LAw § 751 (McKinney 1975 \& Supp. 1988); N.C. GEN. STAT. § 5A12 (1981). The purpose of these limits is to protect against the arbitrary exercise of judicial power. See Dobbs, supra note 43, at 268 \& nn.353-54.

63. See supra note 2 and accompanying text.

64. For a general discussion of the various reasons prosecutors decline to pursue cases, see Gittler, supra note 18, at 157-60.

65. "For the prosecutor ... the possibility that a given case will result in actual conviction is the most important consideration of the charging process." A. BLUMBERG, supra note 5, at 125.

66. See id. at 124 (Since prosecutorial resources are limited "it is impossible to prosecute many offenses [and] ... offices of prosecution have to establish their own order of priorities in the allocation of scarce resources.").

67. For a description of the overwhelming easeload in the United States Attorney's Office, see United States ex rel. Vuitton et Fils S.A. v. Karen Bags, 592 F. Supp. 734, 744 \& n.5 (S.D.N.Y. 1984), aff'd sub nom, United States ex rel. Vuitton et Fils S.A. v. Klayminc, 780 F.2d 179 (2d Cir. 1985), rev'd sub nom. Young v. United States ex rel. Vuitton et Fils S.A., 107 S. Ct. 2124 (1987).

68. "It is commonly assumed that the prosecutor should give precedence to cases involving serious crimes in allocating his time and resources." F. MILler, ProseCUTION 161 n.22 (1969); see also C. Bartollas, S. Miller \& P. Wice, Participants in American Criminal Justice 152 (1983) ("The selection process involves deciding which eases are most serious and in need of prosecution and which appear to present the lcast amount of potential danger to the community."); J. Wilson, Crime and Public Policy 170 (1983) (citing studies which "agree that prosecutors" 
characteristics of the crime victim, ${ }^{69}$ political influences, the prosecutor's career concerns, ${ }^{70}$ and personal feelings ${ }^{71}$ often figure prominently in the prosecutorial decision.

As a result of the various factors that influence prosecutorial discretion, government prosecutors annually dismiss or fail to charge many cases that justify criminal prosecution. ${ }^{72}$ For many crime victims, therefore, the criminal justice system does not provide a reliable means of deterring the perpetrator from striking again.

Thus, the array of remedies offered the crime victim under the current legal system may be inadequate to protect him or her from repeated victimization. Civil and equitable actions may prove insufficient or impractical deterrent measures. The alternative, a criminal action, may be precluded by the district attorney's refusal to press charges. A crime victim in this position should have some legal means of deterring the

case-screening and handling decisions have been infuenced primarily by the strength of the evidence and the seriousness of the offense").

69. District attorneys evaluate the prospects for successful prosecution of a case, in part, by predicting how a judge and jury will react to the particular victim on the stand. If the victim fits the prosecutor's conception of the credible complaining witness, then the prosecutor will have greater confidence that the factinder will be persuaded to convict. Prosecutors "are prone to attribute credibility to certain types of individuals, those who fit society's stereotypes of who is credible: older, white, male, employed victims." Stanko, The Impact of Victim Assessment on Prosecutors' Screening Decisions: The Case of the New York County District Attormey's Office, 16 LAW \& Soc'Y REv. 225, 229 (1981-82). A recent study suggests that extraneous factors such as the race of victim and defendant may also influence a prosecutor's sentencing strategies. The study found that prosecutors in South Carolina are more likely to seek the death penalty for a black person's murder of a white victim than for a white person's murder of a black victim. No other circumstances besides race account for this difference. Patemoster, supra note 35 , at 766-85.

70. Since many prosecutors view their position as a stepping stone to higher political office, they naturally select those cases that will enhance their professional image. Comment, supra note 18, at 210 \& n.7. "Prosecutors always want 'good' publicity, and are strongly tempted to acquiesce to political pressures or popular opinion." A. BLumBerg, supra note 5, at 123.

71. A prominent historical example of the prosecutor's personal involvement in the charging decision is Attorney General Robert Kennedy's persistent prosecution of Jimmy Hoffa. C. Bartollas, S. Miller \& P. Wice, supra note 68, at 152.

The United States Supreme Court has acknowledged that prosecutorial discretion should not reflect the prosecutor's personal feelings. Blackledge v. Perry, 417 U.S. 21, 25-29 (1974) (holding that a prosecutor could not enhance a charge out of "vindictiveness," in retaliation for the defendant's exercise of his right to de novo appcal); see also Comment, Prosecutorial Vindictiveness: An Examination of Divergent Lower Court Standards and a Proposed Framework for Analysis, 34 VAND. L. REv. 431 (1981) (examining judicial responses to prosecutorial vindictiveness).

72. "Many persons who are in fact guilty of a crime and who could be convicted are ... not charged at all ..." F. MILLER, supra note 68, at 154. It is impossible to derive statistics as to the number of cases that are worthy of prosecution which nevertheless are purposely neglected each year. The disparity in prosecution rates between different prosecutor's offices, however, indicates the degree to which prosecutorial discretion screens out charges. For example, while the district attorney's office in Santa Monica, California rejected only $17 \%$ of the robbery arrests in its jurisdiction, the office in Pasadena failed to prosecute $63 \%$ of its robbery arrests. D. GREENWOOD, S. Wildhorn, E. Poggio, M. Sturnwasser \& P. Deleon, Prosecution of Adult Felony DEFENDANTS 88 (1976); see also Barnett \& Hagel, supra note 7, at xviii (noting that approximately half of police arrests do not result in prosecution). 
perpetrator froin inflicting further harm. Specifically, the crime victim in this predicament should have the right to seek a criminal prosecution from the court.

\section{II \\ The Proposed Procedure}

This Part proposes a method of providing deterrent relief for those victims who are left without a legal means of protection. It outlines a procedure whereby a victim can petition for and obtain a judicially initiated criminal prosecution. ${ }^{73}$ The functional design of this proposal is patterned after an analogous procedure that already exists in the federal system - the judicial appointment of private attorneys to prosecute criminal conteinpt charges under Federal Rule of Criminal Procedure 42(b). ${ }^{74}$ As in the Rule 42(b) scheine, this proposed procedure functions in three definable stages: (1) the victim's petition for prosecution; (2) the judicial appointment and payinent of the private prosecutor; and (3) the actual prosecution. ${ }^{75}$ This Part will describe each step of the process.

\section{A. The Victim's Petition for Court-Initiated Prosecution: The Requisite Showing}

\section{Standing}

A victim may invoke this proposal only if he or she alleges a sufficient interest in the criminal prosecution. Under traditional standing doctrine, victims norinally may not assume any role in criminal prosecutions. In Linda R.S. v. Richard D., the United States Supreme Court held that "a private person lacks a judicially cognizable interest in the prosecution or nonprosecution of another."76 There, a mother sought to compel the district attorney to prosecute the father of her child for failing to make statutorily-mandated child support payments. Although the mother demonstrated that the father's delinquency caused her an "actual injury," the Court held that she lacked standing to contest the district

73. This Comment suggests that the proposal be implemented by legislation, and not by the courts under their supervisory powers. In the past, courts have expanded their powers by judicial review and statutory interpretation. See, e.g., supra note 57. Since this proposal represents a significant redefinition of the judiciary's role and responsibilities in criminal cases, however, its guidelines should be articulated by the legislature and clearly codified.

74. FED. R. CRIM. P. 42(b).

75. See supra note 57. Typically, the private beneficiary of a violated injunction initiates the process by petitioning the court to appoint a prosecutor. See, e.g., Young v. United States ex rel. Vuitton et Fils S.A., 107 S. Ct. 2124, 2129 (1987). The court then reviews the petitioner's affidavits to determine if there is probable cause that the enjoined party has violated the judicial decree. If this showing is satisfied, the judge appoints a private attomey to prosecute the criminal contempt charge. Id. at 2137.

76. 410 U.S. 614,619 (1973). 
attorney's refusal to file charges because there was no "direct nexus" between her claimed interest and the criminal prosecution of the father. ${ }^{77}$ Criminal prosecution would not advance the mother's interest in securing the delinquent support payments since the father would be incarcerated if convicted, and would not be forced to pay child support.

On its face, the restrictive language of Linda R.S. appears to deny victims any say im the prosecutorial process. Nonetheless, as the Second Circuit Court of Appeals explained in Inmates of Attica Correctional Facility v. Rockefeller, ${ }^{78}$ crime victims sometimes can demonstrate the "direct nexus" that the mother lacked in the Linda R.S. case.

In Inmates of Attica, prison inmates sought a judicial order to compel a state investigation and prosecution of incidents of physical abuse perpetrated by certain prison officials. The inmates alleged that they had suffered past injuries and that this abuse would continue unless the responsible officials were prosecuted: ${ }^{79}$ While the Second Circuit refused to compel prosecution on separation of powers grounds, it did distinguish the inmates' cause of action from the mother's suit in Linda R.S. In Linda R.S., the court explained, the mother lacked a sufficient interest in the prosecution because she sought criminal sanctions to induce the defendant to make the support payments. In Inmates of Attica, by contrast, a stronger interest existed because the inmates sought to deter a harmful act rather than to induce a beneficial one. "Where a successful prosecution ... would serve to deter the accused from harming the complainant ...., the complaining person does show a more direct nexus between his personal interest in protection from harm and the prosecution." 80

Since they possess the saine interest as the plaintiffs in Inmates of Attica in deterring an offender from future criminal activity, crime victims who qualify for this proposal also have the requisite "direct nexus" to establish standing. ${ }^{81}$ Thus, those petitions which allege a personal

77. Id.

78. 477 F.2d 375 (2d Cir. 1973).

79. Id. at 378 .

80. Id.

81. The possibility that the judge will order the criminal defendant to make restitution could also constitute a personal interest that arguably justifies victim participation in criminal prosecution. The Victim and Witness Act of 1982, for instance, provides that a federal court "may order, in addition to or in lieu of any other penalty authorized by law, that the defendant make restitution to any victim of the offense." 18 U.S.C. \& 3579(a)(1) (1982). Under this remedy, the victim may recover for property losses, and in the case of bodily injury, for medical and related expenses and for lost income. Id. \$ 3579(b)(2) (1982).

Professor Goldstein argues for a system in which restitution to the victim replaces punishment as the end result of prosecution for certain categories of crimes. As the beneficiaries of such prosecution, victims therefore have a potential property interest in the proceedings. Consequently, his plan recognizes a "genuine right of victims to participate as parties in those parts of the process ... where they have a special stake, as in restitution." Goldstein, supra note 18, at 561; see also 
interest $\mathrm{m}$ deterring revictimization can overcome the traditional restriction on private party standing in criminal inatters. ${ }^{82}$

\section{Merits}

Once tlie victim's petition establishes standing by alleging a sufficient deterrence interest in the prosecution, it must make two specific showings to convince the court to appoint an attorney to prosecute the alleged offender: (1) that the accused actually committed the alleged crime, and (2) that appointment of a private prosecutor is necessary to prevent irreparable harm to the petitioner.

First, like a public prosecutor seeking to initiate a regular prosecution by information or indictment, the victim must present evidence indicating that the subject of the proposed prosecution is the perpetrator of the crime. Prosecution under this proposal will be available only if the victim's petition establishes probable cause tliat the suspect is guilty. ${ }^{83}$

Barnett \& Hagel, supra note 7, at 25-30 (discussing restitutionary theory in the criminal justice system).

If a potential restitutional imterest justified victim-initiated prosecution under the proposal advocated by this Comment, the broad scope of section 3579 would qualify most victims for standing to invoke the procedure. This proposal, however, is specifically intended to provide a victim the means of deterring likely future victimization, not to create an opportunity to seck restitution through criminal prosecution. A restitutionary interest ean be pursued in a civil action.

82. A reviewing court would be more willing to accept this proposed procedure than the mandamus action in Linda R.S. because the procedure does not infringe prosecutorial autonomy to the same degree. In Linda R.S., the mother sought to force the prosecutor to take affirmativc action-file a charge. The protection of prosecutorial autonomy was clearly a inajor concern underlying the court's decision that the mother "lack[ed] standing to contest the policies of the prosecuting authority." 410 U.S. at 619. In fact, the cases cited for this proposition allude to this concern. See Younger v. Harris, 401 U.S. 37, 45 (1971) (" "O]rdinarily, there should be no interferencc with ... officers . . . charged with the duty of prosecuting offenders against the laws of the State ... . ") (quoting Fenner v. Boykin, 271 U.S. 240, 243 (1926)); Poe v. Ullman, 367 U.S. 497,502 (1961) (the courts should respect the " '[d]eeply embedded traditional ways of carrying out state policy" " (quoting Nashville, C. \& St. L. Ry. v. Browning, 310 U.S. 362, 369 (1940)).

This proposal, by contrast, does not implicate the same concern. It does not permit a court to compel the prosecutor to do anything. Rather, this proposal inerely gives a court the authority to prosecute a charge on its own, one that the prosecutor has already refused or ignored.

83. In a similar context, courts have used the probable causc standard to determinc whether a private party's allegations of criminal contempt are sufficient to justify court appointment of a private prosecutor under Rule 42(b). The trial court in United States ex rel. Vuitton et Fils S.A. v. Karen Bags, Inc., 592 F. Supp. 734, 742 (S.D.N.Y. 1984), aff'd sub nom. United States ex rel. Vuitton et Fils S.A. v. Klayminc, 780 F.2d 179 (2d Cir. 1985), rev'd sub nom. Young v. United States ex rel. Vuitton et Fils S.A., 107 S. Ct. 2124 (1987), made the appointinent after finding the allegations and evidence in Vuitton's affidavits sufficient "to establish probable cause that a course of conduct had already commenced which was contumacious of the Court's orders in the Vuitton litigation." See also In re United Corp., 166 F. Supp. 343, 345 (D. Del. 1958) ("Before entertaining an application for the appointment of an attorney to prosecute a crininal contempt in behalf of this court, ... [ the trial judge] insist[s] upon a showing of probable cause."); Bowles v. Bullock, 5 F.R.D. 147, 148 (D. Del. 1945) (a petition seeking prosecution of criminal contempt for violation of court order "must have the same specificity as an indictinent or an information").

To prevent use of this proposal to bring unwarranted prosecutions, the judge must carefully 
The second requirement-that failure to appoint a private prosecutor would cause the victim irreparable harm-could be established by the same standard required of a party seeking an equitable injunction. This standard is appropriate because, like an injunction, the purpose of this proposal is to prevent future harmful conduct. Accordingly, the petitioner must show: (1) that there is a "reasonable likelihood of violations of law $\mathrm{m}$ the future"84 causing irreparable harm to the petitioner; and (2) that no adequate remedy or rehef exists at law to protect the petitioner's interests. ${ }^{85}$

Victims can show a reasonable likelihood of revictimization by demonstrating that the offender's prior criminal persecution indicates an ongoing course of criminal conduct. The second showing, that alternative remedies are inadequate, involves several inquiries. First, the victim must show that the district attorney has refused to file charges, thus eliminating criminal prosecution through that office as a potential reinedy. ${ }^{86}$ Second, the victim must convince the court that civil damages are ineffective either because the offender is insolvent and therefore judgmentproof, or because damages would not deter the offender from continued violation. ${ }^{87}$

Finally, the victim must present evidence indicating a strong likelihood that an injunctive order would not deter the offender. ${ }^{88}$ Such evi-

review this showing. Although probable cause is the minimum standard, courts may, in their discretion, adhere to the standard that United States Attorneys follow when deciding whether to seek an indictment to prosecute: one should bring an indictment only when it appears, on the basis of the evidence, that a jury would convict. UNITEd STATES ATtORNEYs' MANUAL, § 9-27.220 (1984).

84. See supra note 40 and accompanying text.

85. See supra note 41 and accompanying text.

86. This is a strict requirement with no exceptions. The purpose of this proposal is to protect the crime victim's deterrence interests in a criminal prosecution, not to afford the victim a choice of prosecutors. The Young Court suggested the same in the contempt context: "[A] court ordinarily should first request the appropriate prosecuting authority to prosecute contempt actions, and should appoint a private prosecutor only if that request is denied." Young v. Umited States ex rel. Vuitton et Fils S.A., 107 S. Ct. 2124, 2134 (1987). The denial need not be explicit under this proposal. Since the victim may be harmed in the future, this proposal requires some time-limit for the pnblic prosecutor's consideration of the case. Failure to file charges within a prescribed time after the complaint signifies a refusal to prosecute, allowing the victim to file a petition.

Note also that the proposal does not challenge the public prosecutor's discretionary power to reduce a charge through plea-bargaining. Under the proposal, the victim is precluded from petitioning the court once the prosecutor brings charges, even if the prosecutor has bargained the charge down to a lesser offense than originally arrested for. Any criminal charge, no matter how serious, provides the deterrence that this proposal is designed to ensure. The proposal therefore operates only upon the public prosecutor's refusal or disinissal of a charge.

87. See supra text accompanying notes 38-39.

88. See supra notes $42-62$ and accoinpanying text. The Second Circuit applied a similar analysis in Ininates of Attica Correctional Facility v. Rockefeller, 477 F.2d 375 (1973). In dicta, the court stated that a victim may have standing to compel prosecution only if he or she shows that a previously secured imjunction failed to halt the criminal conduct. Id. at 378 . While, in Inmates of Attica, such a determination occurred after imjunctive rehef had been attempted, the case does 
dence might include a previous disregard for court orders, a general disrespect for the law, a demonstrated pattern of persecuting the victim, de facto immunity from inonetary contenipt penalties due to insolvency, or a lack of concern for avoiding the reputational damage caused by criminal contenupt conviction. For example, a solvent corporate offender with no record of prior offenses against the victim or of previous conteinpt violations, and with an institutional concern for its reputation would probably not fit the requisite profile. As an injunction would probably deter this defendant, the victim must seek that remedy first. Only if that injunction is subsequently violated may the victini then pursue prosecution under this proposal.

\section{B. The Judicial Appointment and Payment of the Private Prosecutor}

If the judge determines that the victim's petition demonstrates the existence of probable cause and the need for exceptional relief, then he or she may approve the petition. The criminal proceedings will then commence unless the executive exercises its power to immediately appeal the appointment to an appellate court. ${ }^{89}$ The public prosecutor's office may convince a reviewing court to drop the charge only if it successfully refutes the court's determination that the cliarge is warranted by the facts, or demonstrates that the cliarge is contrary to public policy. ${ }^{90}$ Unless the executive takes this extraordinary step and makes the requisite slowing, the trial judge may apponit a prosecutor for the charge. ${ }^{91}$

Because of the Young restriction, however, the judge cannot appoint

illustrate one instance where a victim may have a right to invoke criminal prosecution based on the ineffectiveness of alternative remedies.

89. The public prosecutor must receive notice upon the victim's filing of a petition. The executive may then make its appeal directly after the court finds the victim's petition meritorious.

90. The Ethics in Government Act, 28 U.S.C. $\$ \S 591-598$ (1982), which permits the judiciary to appoint prosecutors to investigate and prosecute criminal activity by certain high government officials, see infra text accompanying notes 166-71, provides the executive a similar power, the power of removal. 28 U.S.C. $\$ 596(a)(1)$ (1982). Once the Attorney General exercises this power, the imdependent counsel can obtain judicial review of this removal. 28 U.S.C. $\$ 596(a)(3)$ (1982). The reviewing court will not permit the removal unless the executive demonstrates "good cause." 28 U.S.C. § 596(a)(1) (1982).

Under this proposal, the executive has the same power to appeal the court's appointment for "good cause." The court will vacate the charge only if the exccutive presents a valid reason based on the merits of the case or public policy grounds. A valid policy reason might be, for example, that the government is currently trying to regulate the illegal activity underlying the court's charge through other, non-crimimal means-such as regulatory actions. See infra note 180 . Note, however, that the availability of resources, a major element in executive charging decisions, see supra notes 66.68 and accompanying text, is not a valid policy reason since the government prosecutor's office does not finance court-initiated actions under this proposal.

91. This check on the judiciary's power to bring prosecutions is important in conforming the proposal to the constitutional separation of powers between the branches of federal government. For a discussion of how the proposal may be implemented by the federal government without violating the separation of powers, see infra text accompanying notes 148-83. 
the victim's attorney; the appointed prosecutor must be "disinterested."92 Although the Young disinterestedness requirement applied specifically to criminal contempt prosecutions in the federal courts, this Comment accepts its fairness rationale and apphes it to all prosecutions under this proposal.

The requirement that a private prosecutor be dismterested poses the same practical problem that arose in the contempt context: how to fund the prosecution. If the interested party is not permitted to retain the prosecutor, and the public attorney refuses to prosecute or bear the cost, there is no one to pay the private prosecutor. ${ }^{93}$ This problem may be overcome, however, by requiring the victim (or private groups that represent the victim's interest) to place funds equal to the estimated cost of prosecution in a court-controlled trust, upon approval of the petition. ${ }^{94}$ The judge then appoints a private attorney, one entirely unassociated with the petitioner, who receives payment from the trust. ${ }^{95}$ This arrangement permits private parties to finance the prosecution without creating an improper influence upon the conduct of the prosecution. The appointed prosecutor tlius remains "disinterested."96

92. See supra notes 58-59 and accompanying text.

93. See supra note 61 and accompanying text.

94. This fund could include court costs as well as the cost of prosecution. Special funds could also be provided to protect indigent victims. For example, since victims of spouse abuse frequently lack the means to retain counsel, local charitable agencies (e.g., shelters, victims rights groups) might be enlisted to create a fund for the prosecutions. In this manner, the prosecution of a crime under this proposal would be achieved at no public expense.

95. Before implementing this proposal, a legislature should study the policies and procedures for appointing defense counsel in jurisdictions that employ private attorneys to represent indigent criminal defendants. An effective system might have local bar associations make members available for this prosecution duty, as many do for the defense of indigents. See The Recorder, Jan. 11, 1988, at 1 , col. 1 for a description of the indigent defense program operated by the San Mateo County Bar Association.

These systems might also suggest practical ways to institute a payment scheme for this proposal. For instance, a court could impose a flat fee schedule rather than an hourly rate to encourage the attorney to work more quickly, or at least the court could reduce the hourly payment if an attorney needlessly prolongs the proceedings. See Taylor, A Needed Legal Specialty: The Special Prosecutor, 61 Judicature 220, 223-24 (1977) (proposing that California appoint private attorneys to prosecute certain cases and allocate funds to pay these appointees as the state currently does for defense of indigent criminal defendants).

96. In addition to the disinterestedness problem, the appointment of counsel raises special concerns regarding the role of the victim. Specifically, the victim should not be allowed to bring charges simply to coerce some concession from the defendant and then abandon the prosecution once the desired result is achieved. Not only does such abandonment waste judicial and prosecutorial resources, it also exposes the government to the larger problem of double jeopardy; the government would be precluded from ever bringing the same criminal charges on its own. U.S. CONST. amend. V ("nor shall any person be subject for the same offence to be twice put in jeopardy of life or limb"); see Benton v. Maryland, 395 U.S. 784 (1969) (applying the constitutional guarantee against double jeopardy to the states).

Under this proposal, a victim would be required to cooperate as a complainant/witness throughout the proceeding, or face the penalty of contempt. Similar safeguards against abuse have been implemented where private parties have a say in the charging decision. See, e.g., Parnas, 


\section{The Proceedings}

Once the judge approves the victim's petition and appoints the private prosecutor, the appointed attorney is authorized to investigate and prepare a case against the defendant. From this point forward, the private prosecutor enjoys all the powers and responsibilities of the public prosecutor. ${ }^{97}$ First, the prosecutor takes the preliminary steps required by the law of the relevant jurisdiction and argues the preliminary hearmg. ${ }^{98}$ Then, to get full authorization to proceed, the prosecutor either files an information, ${ }^{99}$ or, as required in federal felony cases, ${ }^{100}$ presents evidence to a grand jury and secures an indictment.

Once a charge is brought, the private attorney conducts the prosecution within his or her discretion as the representative of the state. Like the public prosecutor, the appointed attorney investigates the case, litigates pretrial motions, plea bargains with willing defendants, decides a trial strategy, conducts the trial, and recommends the sentence where appropriate.

Unlike the public prosecutor, however, this attorney's conduct is subject to especially close judicial scrutiny. Since the appointed attorney may be inexperienced as a prosecutor, the presiding judge needs to carefully supervise the prosecution and remam alert to any possible violations of the defendant's riglit to a fair trial. ${ }^{101}$ Especially im those stages of the

Prosecutorial and Judicial Handling of Family Violence, 9 CR1M. L. BULL. 733, 738-739 (1973) (some prosecutors' offices impose penalties, such as court costs, upon victims of family violence who fail to cooperate after insisting on prosecution); see also Comment, supra note 18, at 233 (author's proposed system of private prosecution would prohibit discontinuance of the proceedings by the private prosecutor without the court's consent, under penalty of contempt).

97. A similar allocation of broad powers is found in the Ethics in Government Act, 28 U.S.C.A. $\S \S 591-598$ (1982). In this statute, Congress provides that an independent prosecutor, appointed by the judiciary to investigate and prosecute alleged criminal activity by high-ranking government officials, shall have "full power and independent authority to exercise all investigative and prosecutorial functions and powers of the Department of Justice, the Attorney General, and any other officer or einployee of the Departinent of Justice [with the narrow exception of wiretapping]." Id. at $\S 594(\mathrm{a})$.

98. The federal mles grant felony defendants the right to a preliminary hearing. FED. R. CRIM. P. 5(c).

99. See generally W. LaFave \& J. Israel, Criminal Procedure § 14.2(d), at 602 (1985) (explaining prosecution by information).

100. "No person shall be held to answer for a capital, or otherwise infamous crime, unless on a presentment or indictment of a Grand Jury ...." U.S. CONST. amend. V. A criminal defendant in a federal court has the right to indictment by grand jury if charged with an offense punishable by death or by imprisonment for over one year. FED. R. CRIM. P. 7(a).

101. This proposal requires the court to be active in the proceedings-nore active than in most criminal prosecutions. It must review the petition for standing, probable cause and the need for exceptional relief; appoint the private prosecutor; exercise authority over the prosecutor's compensation; and closely supervise the prosecutor's conduct. However, none of these tasks is foreign to a trial court; trial courts already perform all of them in various other contexts.

Judicial review of showings of standing, probable cause and need for extraordinary relief is far froin unprecedented. Trial judges make standing determinations when they evaluate a party's 
proceedings where the prosecutor enjoys broad discretionary authority, the court has the responsibility to scrutinize that attorney's conduct and decisionmaking. ${ }^{102}$ When the appointed prosecutor plea bargains with the defendant and recommends a reduced charge, for example, the court needs to exercise its power to review the charge and reject the guilty plea if the charge is not appropriate. ${ }^{103}$

This procedure, therefore, provides the crinie victim with a practical neans of deterring revictimization through judicially initiated prosecution. By carefully defining the design and scope of the proposal, this Part has denionstrated that such a procedure can conform to the practical requirenents of standing and disinterested prosecution. The next question is whether this proposal can conform to the constitutional requirements of due process and separation of powers.

\section{III}

\section{Constitutional Analysis of the Proposal}

This proposed realignment of prosecutorial discretion runs counter to traditional procedure and the current power allocation within the criminal justice system. Consequently, it raises a number of constitutional questions. Specifically, one might argue that the proposal violates

interest in reviewing intervenor applications. See, e.g., Shapiro, Some Thoughts on Intervention Before Courts, Agencies, and Arbitrators, 81 HARv. L. REV. 721, $721-56$ (1968) (discussing issues presented by an intervention request). Judges presiding over preliminary liearings decide whether probable cause exists to believe that the defendant committed the alleged crime. W. LAFAVE \& J. ISRAEL, supra note $99, \S 1.4(\mathrm{i})$, at 14-15. Judges also examine the need for extraordinary relief in equitable actions for injunctions. See, e.g., Hunble Oil \& Refining Co. v. Harang, 262 F. Supp. 39, 42 (E.D. La. 1960) ("The granting or denial of a preliminary injunction rests ... in the discretion of the trial court.").

Federal courts currently exercise authority to appoint prosecutors under Rule 42(b). See supra note 57 and accompanying text. Also, courts are involved in administering attorney compensation. Judges have historically determined the amount of fee awards to the plaintiff's attorney in class actions when the fees are not fixed by contract. See, e.g., Developments, Class Actions, 89 HARv. L. REv. 1319, 1607 (1970) (the court can set the class attorney's fee when there is no contract, and even has the power to revise a contractually established fee amount). Finally, judicial supervision of appointed prosecutors is a recognized responsibility of the federal trial judge in criminal contempt proceedings under Rule 42(b). See United States ex rel. Vuitton et Fils S.A. v. Klayminc, 780 F.2d 179, 184 (2d Cir. 1985) (special prosecutors appointed under Rule 42(b) are kept "under close judicial scrntiny"), rev'd sub nom. Young v. United States ex rel. Vuitton et Fils S.A., 107 S. Ct. 2124 (1987).

102. The exeeutive may also request removal of the appointed prosecutor upon a demonstration of the prosecutor's inisconduct. If the public prosecutor presents evidence that the appointed attorney has conducted himself improperly or has a personal interest in the proceedings, the court should withdraw the appointment and choose a new prosecutor. This inechanism permits the executive to retain some supervisory control over the prosecution. As the Supreme Court held in Morrison v. Olson, No. 87-1279, ship. op. at 33-34 (U.S. 1988), the executive's statutory authority to remove the court-appointed proseeutor for "misconduct" validated the Ethics in Government Act under the constitutional separation of powers.

103. The Federal Rules of Criminal Procedure vest the judge with power of final approval of guilty pleas. FED. R. CRIM. P. 11 . 
the fifth and fourteenth amendments' guarantees of due process or the doctrine of separation of powers. ${ }^{104}$ This Part will demonstrate that the proposal passes muster under both constitutional doctrines.

\section{A. Due Process}

A defendant prosecuted under the proposed procedure might challenge it on due process grounds. ${ }^{105} \mathrm{As}$ in all procedural due process cases, the defendant would assert hiberty and property interests in not being subjected to criminal sanctions without due process of law. ${ }^{106}$ The constitutional guarantee of due process provides, in essence, that any sanction that deprives the defendant of life, liberty, or property "be impleinented in a fair manner."107

To show that this proposal violates due process, the challenger inust deinonstrate that it so deviates froin existing criminal procedure as to undermine the required fairness of criminal proceedings. Since the inain

104. One might also challenge this proposal on grounds that it violates the constitutional guarantee to equal protection under the law. Two different equal protection claims might bc raised. First, one might argue that a suspect's chances of being prosecuted under this proposal depend on whether the victim has the resources, time, and inclination to pursue the prosecution. Therefore, one who injures a wealthy victim would face a higher probability of prosecution under the proposal than one who injures a poor victim.

As the criminal justice system currently operates, however, suspects already face varying risks of prosecution. A suspect's chances of being prosecuted are based upon numerous factors including economic and political infiuences. See supra notes 64-72 and accompanying text. Thus, for example, if a particular district attorney's office has scarce resources and a heavy caseload, it may decide not to prosecute a certain criminal charge. Once these fiscal and workload pressures subside, however, the office might prosecute that same offense.

Sccond, this proposal possibly discrimmates against poor victims. Since they cannot afford to pay the lawyer's fees, they are effectively denied this remedy. This should not raise an equal protection problem because the victim's interest in prosecution under this proposal is a civil interest in enjoining future harm. The Constitution does not place the government under a duty to provide all persons access to the civil courts if they cannot afford the action. Similarly, there is no constitutional right to protect this civil injunctive interest through criminal proceedings under this proposal.

Nevertheless, a legislature wishing to equalize access to the remedy under this proposal could allocate government funds to pay the appointed prosecutor whenever a successful petitioner is indigent. This program could be patterned after the common arrangement whereby states pay private counsel to defend imdigent crimimal defendants. See supra note 95.

105. The defendants convicted of criminal contempt by the court-appointed prosecutor under Federal Rule of Crimmal Procedure 42(b) in Young v. United States ex rel. Vuitton et Fils S.A., 107 S. Ct. 2124 (1987), challenged the appointment of private prosecutors on due process grounds. See Brief for Petitioners at 15-34, id. (Nos. 85-1329 and 85-6207)

106. The due process clause of the fifth amendment provides that "[n]o person shall . . . be deprived of life, liberty, or property, without due process of law." U.S. ConsT. amend. V. The due process clause of the fourteenth amendment applies the same prohibition to state governinents. U.S. CONST. amend. XIV.

107. United States v. Salerno, 107 S. Ct. 2095, 2101 (1987); see also Daniels v. Williams, 474 U.S. 327, 337 (1986) (Stevens, J., concurring) ("the State may not execute, imprison, or fine a defendant without giving him a fair trial"); In re Murchison, 349 U.S. 133, 136 (1955) ("A fair trial in a fair tribunal is a basic requirement of due process."). 
innovation of this proposal is to replace the public prosecutor with a private prosecutor, any due process challenge would involve an alleged right to be prosecuted by a public prosecutor.

The United States Supreme Court has used various tests to determine whether certain criminal procedures comply with due process. An examination of the proposal under each of these tests will demonstrate that it operates within the guidelines of the due process clause.

\section{Textual Enumeration}

A court reviewing the validity of this proposal would look first to the text of the Constitution itself. If prosecution by a public prosecutor were an enumerated right of criminal defendants, like the sixth amendment right to defense counsel, the government would owe a duty to use only public prosecutors. Since the document mentions no such right, however, the defendant has no textual basis for a constitutional challenge.

\section{Tradition}

In the absence of textual guidance, courts typically determine the constitutionality of a challenged procedure by analyzing whether it conflicts with the traditional Anglo-American conception of fairness in criminal proceedings. ${ }^{108}$ An examination of American legal tradition demonstrates that a criminal defendant has no fundamental right to prosecution by a public attorney. Although public prosecution is the norm in inost criminal proceedings, this country has a strong and continuing tradition of criminal prosecution by private parties. Private parties, in fact, prosecuted all criminal cases in English and American common law, before the divergence of tort and criminal law and the creation of the public prosecutor's office. ${ }^{109}$

Private parties still participate to varying degrees im state and federal

108. In Synder v. Massachusetts, 291 U.S. 97 (1934), for example, the Court thoroughly examined English and American precedents to determine whether the practice of pointing out relevant objects during a jury's viewing of the scene of the crime offended a principle of justice "rooted in the tradition and conscience of our people." Id. at 111.

The United States Supreine Court has announced several formulations of this test. In deciding whether a particular procedural protection is constitutionally required, it has considered whether that procedure "is implicit in the concept of ordered liberty." Palko v. Connecticut, 302 U.S. 319, 325 (1937) (examiring whether the fourteenth amendinent applies the fifth amendinent immunity from double jeopardy to the states). In examining the constitutionality of certain police practices, it has asked whether they "shock[] the conscience." Rochin v. California, 342 U.S. 165, 172 (1952) (police-coerced vomiting to retrieve evidence froin suspect's stornach violates the due process clause). Ultimately, all these formulations simply ask whether a challenged criminal procedure "offends soine principle of justice so rooted in the traditions and conscience of our people as to be ranked as fundamental." Snyder, 291 U.S. at 105.

109. See Cardenas, supra note 1 , at 359-72. 
prosecutions today. In state courts, participation by private parties ranges from informal input into the charging decision, to full private prosecution. State prosecutors frequently tailor their charging decision and sentence recommendation to the victim's desires. ${ }^{110}$ Many states give victims a more formal role and permit them to employ special prosecutors to assist in the prosecution. ${ }^{111}$ A few even allow completely private prosecutions, ${ }^{112}$ though usually restricting them to petty offenses. ${ }^{113}$

Some states provide a specific procedure for allocating prosecutorial authority to private parties. The common law qui tam, or informer, action allows a private party to prosecute a criminal defendant and to receive a share of any fine imposed upon conviction. ${ }^{114}$ The United States Supreme Court has upheld this procedure even though it is designed to vest prosecutorial authority and discretion in a private party with personal motives for securing a conviction. ${ }^{115}$

The federal system also allows private parties to perform prosecutorial functions. The Umited States Supreme Court recently authorized private attorneys to prosecute criminal conteinpt charges. ${ }^{116}$ Other federal courts have expressly permitted private counsel to participate in various criminal prosecutions. ${ }^{117}$ In light of this tradition of private participation in state and federal criminal prosecutions, therefore,

110. In serious felony cases, "great weight" is given to a victim's desire to prosecute. Hall, The Role of the Victim in the Prosecution and Disposition of a Criminal Case, 28 VAND. L. REV. 931, 948 (1975) (quoting interview with Robert Schwartz, an assistant district attorney).

111. See, e.g., People v. Farnsley, 53 Ill. 2d 537, 293 N.E.2d 600 (1973); State v. Best, 280 N.C. 413, 186 S.E.2d 1 (1972). This practice is common. See 63a AM. JuR. 2D Prosecuting Attorneys $\S 13$ (1984) ("In many jurisdictions, as was true at eommon law, private counsel employed by the complaining witness' or by other persons desirous of conviction are permitted to assist the prosecuting attorney."); 27 C.J.S. District \& Prosecuting Attorneys $§ 28$ (1959). The states permitting this assistance have placed a variety of restrictions on the degrec of private involvement in criminal prosecution, generally mandating that the district attorney retain a minimum degree of control over the prosecution. This "control," however, may consist only of authorizing the private prosecution. Hall, supra note 110 , at 976 .

112. See, e.g., State v. Cockrell, 131 Mont. 254, 261, 309 P.2d 316, 320 (1957); State v. Ray, 102 Ohio App. 395, 396, 143 N.E.2d 484, 485 (1956).

113. See, e.g., People ex reL. Allen v. Citadel Mgmt. Co., 78 Misc. 2d 626, 630, 355 N.Y.S.2d 976, 981 (Crim. Ct. 1974) (private attorney may prosecute petty offenses).

114. See Crumplar, An Alternative to Public and Victim Enforcement of the Federal Securities and Antitrust Laws: Citizen Enforcement, 13 HARv. J. LEG1s. 76, 80-82 (1975) (explaining that qui tam actions, after falling into disfavor in many jurisdictions, are coming back into use). See generally Comment, supra note 18 , at 222-23.

115. United States ex rel. Marcus v. Hess, 317 U.S. 537, 540-42 (1943).

116. Young v. United States ex rel. Vuitton et Fils S.A., 107 S. Ct. 2124 (1987). The decision invalidated only the appointment of "interested" attorneys, while explicitly upholding the practice of appointing private attorueys to prosecute contempt charges. Id. at 2134.

117. Jones v. Richards, 776 F.2d 1244 (4th Cir. 1985) (upholding conviction obtained by prosecution conducted largely by private attomeys simultaneously involved in civil suit against defendant); Powers v. Hauck, 399 F.2d 322 (5th Cir. 1968) (participation of a special prosecutor alone is insufficient grounds to show violation of defendant's due process rights). 
the guarantee of due process does not include a constitutional right to prosecution by a public attorney.

\section{Balancing Test}

Even though there is no constitutional riglit to public prosecution, the defendant inay challenge the proposed procedure under an alternative test that balances the government's interest in employing a particular procedure against the possibility that the procedure will impair a criminal defendant's ability to receive a fair trial. ${ }^{118}$ In Mathews $v$. Eldridge the United States Supreme Court listed the factors to be weighed in this evaluation. ${ }^{119}$

First, the private interest that will be affected by the official action; second, the risk of an erroneous deprivation of such interest through the procedures used, and the probable value, if any, of additional or substitute procedural safeguards; and finally, the Government's interest, including the function involved and the fiscal and administrative burdens that the additional or substitute procedural requirenent would entail. ${ }^{120}$

Under the Mathews test, this proposal satisfies the due process clause if the governnient's interest in the procedure outweighs any resulting infringement upon the defendant's right to a fair trial. As will be shown, although the procedure affects an important private interest-the defendant's riglit to a fair trial-the risk of erroneous deprivation of that interest is sliglit, and the benefits of the proposed procedure are great.

\section{a. The Impact of the Proposal on the Defendant's Interest}

Under the due process clauses of the fifth and fourteenth aniendnients, the government niay not deprive a criminal defendant of liberty or property witlout a fair trial. ${ }^{121} \mathrm{~A}$ challenger miglit allege that this proposal permits an "erroneous deprivation" of these interests because the involvenient of a private prosecutor undermines the fairness safeguards provided by public prosecution. This proposal, however, main-

118. Due process challenges to criminal procedures often result in balancing tests. See, e.g., United States v. Salerno, 107 S. Ct. 2095, 2102 (1987) (holding that the due process clause does not prohibit pretrial detention under the Bail Reform Act because "the government's regulatory interest in community safety can, in appropriate circumstances, outweigh an individual's liberty interest"); Mapp v. Ohio, 367 U.S. 643 (1961) (applying the exclusionary rule to state courts after balancing the need to deter police violations of privacy against the rule's constraints on law enforcement); see also Comment, supra note 39 , at $789-91$ (discussing various factors to be considered in weighing state versus private interests in a system of private prosecution).

119. 424 U.S. 319 (1976) (finding that the due process clause does not require an evidentiary hearing prior to the termination of Social Security disability payments). Though applied to a civil action in Mathews, courts have subsequently extended this balancing test to criminal procedures. See, e.g., United States v. Raddatz, 447 U.S. 667, 667-81 (1980); Wofford v. Wainwright, 748 F.2d 1505, 1507-08 (11th Cir. 1984).

120. Mathews, 424 U.S. at 335.

121. See supra notes $106-07$ and accompanying text. 
tains both of the protective purposes underlying public prosecution: (1) maintenance of judicial impartiality; and (2) prevention of prosecutorial misconduct.

\section{i. Judicial Impartiality}

The adjudicative ideal in the Annerican criminal justice system requires that a completely inpartial judge weigh the merits of opposing arguments. A defendant's right to a fair trial is compromised if the judge's conduct veers toward prosecutorial advocacy. ${ }^{122}$ Public prosecution maintains judicial impartiality by vesting the decision to prosecute and the control of the prosecution in the public prosecutor. This separation of powers leaves the trial judge hittle opportunity to exert improper influence over prosecutorial decisionmaking. ${ }^{123}$

A challenger might allege that the proposal permits a biased judge to instigate unwarranted prosecutions for improper motives. The proposal, however, imcorporates procedural safeguards to prevent this prob1em. ${ }^{124}$ First, a judge's decision to prosecute on the basis of a meritless petition ${ }^{125}$ could be appealed by the defendant as an abuse of judicial discretion. ${ }^{126}$ Second, just as the traditional due process requirement of

122. The possibility of this was raised as an objection to the judicial appointment power for contempt prosecutions under Federal Rule of Crimmal Procedure 42(b). Note, supra note 1, at 1162-64.

123. Typically, the trial judge plays no part in a criminal case until after the prosecutor has secured an indictment or information. See FED. R. CRIM. P. 7(a) (requiring indictment or information prior to prosecution of criminal offenses).

124. Note that federal judges already enjoy discretionary power to initiatc criminal proceedings for criminal contempt, where the potential for judicial bias against the defendant is especially high. See FED. R. CRIM. P. 42(b). Since coutempt violations directly defy a judge's authority, a judge may take personal offense to such violations, especially if that judge is excessively proud or jealous of his or her authority. See, e.g., Sacher v. United States, 343 U.S. 1, 12 (1952) (explaining that "contempt power over counsel . . . is capable of abuse [since] [m] en who make their way to the bench sometimes exhibit vanity, irascibility, narrowness, arrogance, and other weaknesses to which the human flesh is heir"). Thus, a judge deciding whether to prosecute for contempt may be "unable to hold the balance between vindicating the interests of the court and the interests of the accused." Ungar v. Sarafite, 376 U.S. 575, 588 (1964). Nonetheless, the Supreme Court has upheld the judicial appointment power under Rule 42(b) even though it is particularly conducive to abuse. See Young v. United States ex rel. Vuitton et Fils S.A., 107 S. Ct. 2124 (1987). Consequently, the courts recognize that the appointment power per se does not endanger due process guarantees.

125. See supra text accompanying notes $83-88$ for an explanation of the requisite showings of probable cause and need for relief.

126. This appeal would be the functional equivalent of a defendant's appeal of the magistrate's decision in the preliminary hearing to bind him or her over for information or indictment. In that proceeding a reviewing court determines "whether the examining magistratc abused his discretion in binding the defendant over for trial on the basis of the evidence before him." F. MILLER, supra notc 68, at 147. Even if the prosecutor ultimately accumulates evidence sufficient to secure conviction, insufficiency of evidence to establish probable cause at the preliminary hearing constitutes revcrsible error. See, e.g., People v. White, 276 Mich. 29, 267 N.W. 777 (1936). Similarly, a defendant under this proposal may appeal the judge's approval of the petition on the ground that the victim failed to establish either probable cause or need for relief. See supra text accompanying notes 83-88. 
judicial impartiality mandates reversal of any conviction secured through proceedings infected with judicial bias, ${ }^{127}$ demonstrated bias in the judge's prosecutorial decision will justify reversal of an ensuing conviction.

One might also argue that this proposal permits a judge to appoint an attorney who is subject to his or her influence. A manipulative judge could theu pressure the appointed prosecutor to seek conviction regardless of the merits of the case. Again, however, there is hittle chance that such abuse will occur. Like the government attorney, a private prosecutor is under oath to represent the public interest. Any deviation from. that duty, including unacceptable partisanship, justifies reversal of an ensuing conviction. ${ }^{128}$ Moreover, where the prosecutor brings a meritless case, the adversarial process and the prosecutor's burden of proof should ensure that no conviction occurs.

\section{ii. Prosecutorial Misconduct}

The proposal to place the prosecution in the hands of an appointed private attorney also maintains existing protections against prosecutorial misconduct. First, although the private prosecutor is not governed by all of the institutional safeguards of the public system, he or she is still an unbiased officer of the court. Second, while appointed counsel may be more vigorous im prosecuting than a public prosecutor, this does not in itself constitute misconduct. Finally, although the private prosecutor may be less experienced than the district attorney, sufficient procedural safeguards exist to protect the defendant's due process rights.

Under the prevailing systen, the public prosecutor functions within an institutioual framework designed specifically to promote propriety in criminal prosecutions. The prosecutor is accountable to the public, administrative superiors, and judges. These groups presumably regulate prosecutorial conduct and ensure that the public prosecutor acts as a

127. See, e.g., Ward v. Village of Monroeville, 409 U.S. 57 (1972) (petitioner was denied a fair trial before a disinterested and impartial judge when he stood trial for traffic offenses before the mayor, who was also responsible for village finances and therefore had an interest in collecting fuuds through court-imposed fines); Tumey v. Ohio, 273 U.S. 510, 535 (1927) (a court with a personal financial interest in the outcome of its decisions constitutes an unfair and partial tribunal, violating the fourteenth ameudment).

128. Cf. Marshall v. Jerrico, Inc., 446 U.S. 238, 249-50 (1980) (administrative prosecutors are subject to impartiality requirement); 28 U.S.C.A. $\$ 528$ (West Supp. 1988) (disqualifyiug a federal prosecutor from any litigation which might result in a personal, financial, or political conflict of interest).

Moreover, the danger of judicial manipulation of the appointment process is easily avoided if attorneys are appointed on a rotation schedule overseen by the local bar association, rather than at the judge's personal discretion. See supra note 95 .

Note that the proposal does not pose the opposite danger of judicial manipulation to prevent prosecution of favored defendants, since the public prosecutor still has the opportunity to prosecute alleged criminals. 
disinterested public representative. ${ }^{129}$

Altliough the private prosecutor is not subject to the same institutional constraints as a public prosecutor, he or slie would be no more prone to commit misconduct. Under the proposal, the private counsel has no personal financial or professional interest in the litigation, and therefore no incentive to put personal interests before public interests. ${ }^{130}$ Concededly, factors other than financial mterests may produce a similar bias. Racial or cultural prejudice against the defendant, for example, inay influence a prosecutor's conduct. These other attitudinal factors, however, may be found equally annong private and public prosecutors. Therefore, private prosecutors are no more likely to abuse their discretion than are public prosecutors.

In addition, prosecution by a private attorney does not prejudice tlie defendant even if the attorney pursues a conviction more vigorously than would a district attorney. ${ }^{131}$ With a background in civil litigation or criminal defense, the appoimted attorney might tend toward advocacy ratlier than prosecutorial impartiality. The courts have lield, lowever, that a system that permits the zealous, but disinterested, pursuit of the state's case is not per se unconstitutional. Prosecutors may deviate from the norms of professional conduct so long as their actions do not nake the trial "so fundannentally unfair as to deny [the defendant] due process." 132 In fact, courts acknowledge that prosecutors are not intended to be neutral. "If honestly convinced of the defendant's guilt, the prosecutor is free, indeed obhiged, to be deeply interested in urging that view by any fair means. True disinterest . . . is the doinain of tlie judge and the jury-not tlie prosecutor." 133

129. All these parties influence the district attorney to a certain degree. First, the district attorney is a servant of the public and is particularly subject to public control if selected by public election. Also, the district attorney must answer to superiors in the office and in the political system. Lastly, judges within the district attorney's jurisdiction exert a moderating influence on a district attorney's conduct, as a prosecutor would be ill-advised to antagonize a judge he or she will likcly face again. See generally Cox, Prosecutorial Discretion: An Overview, 13 AM. CRIM. L. REV. 383, 411-32 (1976) (examining the influence exerted on the prosecutor's decisionmaking by the other actors in the criminal justice system).

130. See supra notes $94-96$ and accompanying text.

131. One author, for example, cites the possibility that private prosecutors, bent on conviction, will be unwilling to plea bargain as public prosecutors regularly do. Comment, supra note 39 , at 784-85.

132. Donnelly v. DeChristoforo, 416 U.S. 637, 645 (1974) (prosecutor's improper remark to the jury did not cause sufficient prejudice as to deprive defendant of a fair trial); see also United States v. Monaghan, 741 F.2d 1434, 1443 (D.C. Cir. 1984), (fact that prosecutor overstepped bounds of proper advocacy, in itself, did not violate due process unless substantial prejudice resulted), cert. denied, 470 U.S. 1085 (1985) .

133. Wright v. United States, 732 F.2d 1048, 1056 (2d Cir. 1984) (citation omitted), cert. denied, 469 U.S. 1106 (1985); see also Marshall v. Jerrico, Inc., 446 U.S. 238, 248 (1980) ("In an adversary system, [prosecutors] are necessarily permitted to be zealous in their enforcement of the law."). 
Prosecutorial zealousness raises constitutional issues only when it derives from a "structural" problem im the prosecutorial system that allows prosecutors to operate under a conflict of interest. ${ }^{134}$ As this proposal provides for a disinterested prosecutor, no such structural flaw exists. Hence, the proposal would not violate due process, even if the private attorney argued the prosecution's case with energy and persistence.

Finally, although the private prosecutors may sometimes be mexperienced, ${ }^{135}$ such inexperience poses no threat to the guarantee of due process. The courts have never required prosecutors to have any level of training or expertise beyond the Bar certification. District attorneys often have hittle practical experience in prosecution. As one judge noted, "[i]t is not unusual [for voters] to elect a man prosecuting attoruey who has never actually tried a case." ${ }^{\prime 136}$ Despite the risk of mistakes, courts permit such attorneys to conduct prosecutions. ${ }^{137}$

In sum, neither judicial partiahty nor prosecutorial misconduct affect the constitutionality of criminal proceedings under this proposal. In hight of existing procedural protections and the safeguards built into the proposal, the replacement of the public prosecutor with a courtappointed private prosecutor poses no danger to the constitutional guarantee to a fair trial.

\section{b. The Government's Interest}

Even if this proposal should infrimge upon a defendant's due process interests to some extent, it would still be constitutional under the Mathews balancing test ${ }^{138}$ because the public benefits derived through its implementation outweigh any such infringement. The primary state

134. The conviction in Young was reversed because the judicial appointment procedure, under the courts' interpretation of Federal Rule of Criminal Procedure 42(b), allowed an "interested" counsel to prosecute the charge. Young v. United States ex rel. Vuitton et Fils S.A., 107 S. Ct. 2124, 2137-38 n.18 (1987).

135. One commentator has expressed concern that a private prosecutor with a free rein to investigate may "commit unwitting abuses of his appointed investigative powers simply by not being schooled in police techniques and obligations." Rakoff, supra note 46 , at 5 , col. 3.

136. State v. Harrington, 534 S.W.2d 44, 52 (Mo. 1976) (Holman, J., dissenting).

137. In sixth amendment cases, a defendant's right to effective counsel is not necessarily violated by the appointment of an attorney untrained in criminal defense litigation. United States v. Cronic, 466 U.S. 648, 665 (1984) (indigent defendant convicted of mail fraud received effective assistance of counsel though represented by counsel trained only in real estate law and with no experience in criminal defense). The court will find the representation inadequate only if the defendant demonstrates an identifiable error which has caused actual prejudice to his or her right to a fair trial. Strickland v. Washington, 466 U.S. 668, 687 (1984) (defendant was not denied effective counsel because counsel's conduct was neither unrcasonable nor prejudicial to defendant's case). Similarly, proseeution by inexperienced counsel under this proposal would be constitutional absent unreasonable prosecutorial conduct prejudicial to the defendant.

138. See supra text accompanying notes 119-20. 
interest advanced by this proposal is the protection of crime victims. Currently, most victims have no recognized right to participate in felony proceedings; ${ }^{139}$ the state and the defendant are the only two parties. Consequently, even if a crime victim demonstrates that there is a reasonable likelihood of revictimization by the alleged offender and that the criminal justice system is the only viable means of preventing such harm, the victim has no recourse if the public prosecutor decides not to press charges. Under this proposal, such victims can effectively protect tlieir interests. ${ }^{140}$

Moreover, this remedy provides a warranted and practical check on prosecutorial arbitrariness. ${ }^{141}$ Prosecutors often base tlieir charging decisions on personal and pohtical considerations extraneous to tlie merits of the case. ${ }^{142}$ Existing ineasures for overriding prosecutorial discretionremoval, ${ }^{143}$ writs of mandamus, ${ }^{144}$ and the power to supercede ${ }^{145}$-liave

139. In some states, victims have the right to prosecute defendants for petty offenses. See supra note 113 and accompanying text.

140. Admittedly, this proposal provides a remedy to a restricted group of victims: those who (1) can make the requisite showing in the petition; and (2) either can afford to pay for the courtappointed prosecutor or reside in a jurisdiction that provides funds to pay the prosecutor when the victim is indigent (as suggested supra note 104). Nonetheless, it still provides protection to some victims whose cases are currently overlooked by the criminal justice system.

141. Many commentators have expressed concern that the allocation of unbridled prosecutorial discretion to the public prosecutor opens the door to abuse. See, e.g., Breitel, Controls in Criminal Law Enforcement, 27 U. CHI. L. REv. 427, 429 (1960); Comment, supra note 18, at 209-15 (arguing that existing methods for control of the district attorney's discretion are inadequate to counter abuse of discretion). Since Professor Davis' in-depth study of prosecutorial discretion in Discretionary JUSTICE (1969) several commentators have examined alternative means of regulating the exercise of this discretionary authority. See, e.g., F. MilleR, supra note 68; Abrams, Internal Policy: Guiding the Exercise of Prosecutorial Discretion, 19 U.C.L.A. L. REv. 1, 25-34 (1971) (suggesting publication of prosecutorial policy); Gittler, supra note 18, at 159 (suggesting victim-initiated prosecution as a check on prosecutorial discretion).

142. See supra notes $64-71$ and accoinpanying text.

143. In soine jurisdictions prosecutors can be removed for their failure to prosecute certain charges. See, e.g., State ex rel. Hardee v. Allen, 126 Fla. 878, 172 So. 222 (1937) (upholding governor's power to remove prosecutor guilty of "neglect of duty" for failing to prosecute gambling charges); Attorney General v. Pelletier, 240 Mass. 264, 134 N.E. 407 (1922) (upholding reınoval of prosecutor guilty of foregoing criminal charges against suspects whom he had successfully extorted). This measure, however, applies only in cases of serious inpropriety and is not employed when the prosecutor unreasonably refuses to prosecute a charge. "The district attorney need fear ouster only for criminal activity ...." Id. at 212; see Comment, supra note 35, at 523 (removal is "directed only at the corrupt or incapacitated District Attomey").

144. Victims often urge the courts to issue writs of inandamus, ordering the prosecutor to file charges in a case. But, "the courts thus far are unanimous in holding that inandamus will not issue to compel prosecution." Hall, supra note 110, at 968; see, e.g., Inmates of Attica Correctional Facility v. Rockefeller, 477 F.2d 375 (2d Cir. 1973) (affirming district court's refusal to compel state prosecution); United States v. Cox, 342 F.2d 167, 171 (5th Cir. 1965) (courts may not interfere with prosecutorial discretion).

145. Some states grant public officials, often the attorney general, the power to supercede the district attorney and prosecute a case despite the district attorney's refusal to file charges. See, e.g., CAL. Gov'T CODE $\S 12550$ (West 1980) (Attorney General "shall assist any district attorney in the discharge of his duties, and may, where he deems it necessary, take full charge of any investigation 
proven impracticable in preventing arbitrary decisionmaking because the courts and government officials have been reluctant or unable to invoke thein.

The courts' reluctance to second-guess the decisions of prosecutors stems primarily from the recognition that, im the majority of cases, the prosecutor should enjoy broad discretion in the charging decision. In most situations, the advantages of allocating prosecutorial authority exclusively in the hands of the state ${ }^{146}$ outweigh the potential for arbitrariness. ${ }^{147}$ Where a possibly arbitrary refusal to file charges demes a victim protection from future injury, however, prosecutorial discretion should not be absolute. This proposal provides a necessary check on prosecutorial discretion.

As deinonstrated through the foregoing analysis, this proposal provides for court-imitiated prosecution without exceeding the bounds of due process. Substituting a private prosecutor for the public prosecutor violates no enumerated right. Nor does it run contrary to traditional norms of fairness in the criminal justice system. Fimally, any risk that this proposal infringes on the defendant's right to a fair trial is shight, given the procedural safeguards, and thus the risk of harn is outweighed by the enhanced protection of crime victims.

\section{B. Separation of Powers}

A criminal defendant might also challenge the appointment procedure under the separation of powers doctrine, arguing that the reallocation of charging authority violates the constitutional allocation of powers between the branches of federal government. As the separation of pow-

or prosecution of violations of law of which the superior court has jurisdiction."). State officials are reluctant to use this measure, however, primarily because they have neither the time nor desire to take on the prosecutorial burden themselves. See Comment, supra note 18, at $212 \mathrm{nn} .14$ \& 16; see also Y. Kamisar, W. LAFave \& J. ISRael, Modern Criminal Procedure 900 (6th ed. 1986) (state attorneys general seldom exercise the common law power to supercede the district attorney).

146. This allocation of prosecutorial authority has both practical and constitutional justifications. Courts recognize that prosecutorial decisionmaking requires an expert evaluation of a number of disparate factors, including objectives of executive policy-making. See, e.g., United States v. Cox, 342 F.2d 167, 171 (5th Cir.) (noting that United States Attorneys are executive officials of the government as well as officers of the court), cert. denied, 381 U.S. 935 (1965); Pugach v. Klein, 193 F. Supp. 630, 634 (S.D.N.Y. 1961) (the prerogative of enforcing the criminal law is vested in the executive arm of the government); Note, The Special Prosecutor in the Federal System: $A$ Proposal, 11 AM. CRIM. L. REV. 577, 591-92 (1973); infra note 172 and aecompanying text. In addition, federal courts have interpreted the constitutional doctrine of separation of powers to limit this power to the prosecuting attorney in the executive branch. See infra text accompanying notes 149-51.

147. See, e.g., Abrams, supra note 141, at 3 (noting the "competing tension between the need in prosecutorial decision-making for certainty, consistency, and an absence of arbitrariness on the one hand, and the need for flexibility, sensitivity, and adaptability on the other"); Note, supra note 146, at 592 (explaining that the federal courts, in refusing to second-guess prosecutorial decisions, have determined "that the danger of abuse by the executive is a lesser evil than to render the acts left to executive control subject to judicial encroachment'). 
ers is strictly a federal doctrine, not applicable to the states, the proposal need not comply witli federal separation of powers law when adopted by a state. ${ }^{148}$ Nevertlieless, this Section will demonstrate that the proposal conforins to federal separation of powers.

Since the Constitution restricts Congress' power to allocate authority among the branclies of government, Congress can empower a brancli to undertake certain actions only if that autliorization does not impermissibly infringe powers allocated by the Constitution to another brancli. ${ }^{149}$ Article II, section 3 of the Constitution vests the authority to prosecute criminal offenses in the executive, empowering the President to "take Care that tlie Laws be faithfully executed."150 Interpreting this language, the Supreme Court has establislied the general rule tliat "tlie Executive Brancli lias exclusive autliority and absolute discretion to decide whetler to prosecute a case." ${ }^{151}$ A strict application of this lan-

148. The separation of powers doctrine applies only to the federal government under the United States Constitution. The Constitution does not hold the state governments to the allocation of powers prescribed for the federal government. "All the powers of government may be commingled by any state of the Union without a violation of the United States Constitution." United States v. Solomon, 216 F. Supp. 835, 838 (S.D.N.Y. 1963), quoting Willis, ConSTITUTIONAL LAW 133 (1936).

Although state separation of powers may imitate the federal scheme to a large degree, a state that implements this proposal must analyze its constitutionality under the specific allocation of powers in its own constitution.

149. See, e.g., Nixon v. Administrator of General Services, 433 U.S. 425, $441-43$ (1977) (act permitting public access to papers of former President does not infringe executive's authority under separation of powers).

150. U.S. CoNST. art. II, $\S 3$.

151. United States v. Nixon, 418 U.S. 683, 693 (1974). The "take Care" clause, however, does not necessarily demand this interpretation. Commentators have argued that while this clause does place an affirmative duty on the executive to prosecute violations of the law, it does not vest the executive with the power not to prosecute. See, e.g., Sunstein, Reviewing Agency Inaction After Heckler v. Chaney, 52 U. CH1. L. REv. 653, 670 (1985) ("The 'take Care' clausc is a duty, not a license; it imposes an obligation on the President to enforce duly enacted laws."). Under this interpretation of the Constitution, the executive's negative charging discretion is not sacrosanct, and judicial review of prosecutorial inaction is constitutionally permissible under the federal separation of powers. Note, supra note 18 , at $499-500$.

This interpretation has found support in recent decisions that have construed the "take Care" clause to permit judicial review of an agency's refusal to prosecute regulatory violations. See, e.g., Carpet, Linoleuin \& Resilient Tile Layers Local 419 v. Brown, 656 F.2d 564 (10th Cir. 1981) (permitting mandamus to compel Secretary of Defense to enforce act requiring wage standard); Adams v. Richardson, 480 F.2d 1159 (D.C. Cir. 1973) (ordering Department of Health, Education and Welfare to enforce certain desegregation provisions of the Civil Rights Act of 1964). The courts can review an agency's refusal to enforce a law if, in that law, Congress "has indicated an intent to circumscribe agency enforcement discretion, and has provided meaningful standards for defining the limits of that discretion." Heckler v. Chaney, 470 U.S. 821, 834 (1985).

This reinterpretation could apply to criminal law enforcement as well. "Since the take care clause is the basis of authority for executive enforcement in both the administrative law and criminal law areas, prosecutorial inaction also could be subject to review, should the legislature so provide." Note, supra note 18, at 501-02 (footnotes omitted). Under this view of the Constitution, prosecutorial discretion is not absolute, and judicial review, as proposed in this Comment, is a constitutionally permissible response to prosecutorial inaction. See also Note, supra note 146, at 
guage would preclude the reallocation of prosecutorial discretion proposed by this Comment.

Courts have recognized, however, that the constitutional separation of powers is not iron-clad; powers may shift between the federal branches when a compelling need arises. As the Supreme Court has explained, the Constitution does not "contemplate[ ] total separation of each of these three essential branches of Government."152 In two recent cases, in fact, the Court has taken a "pragmatic, flexible approach"153 to the separation of powers between the executive and judiciary, and has upheld congressional acts that provide for the judicial exercise of prosecutorial functions.

\section{Precedent}

The appoimtments clause of the Constitution ${ }^{154}$ empowers Congress to vest the authority to appoint "inferior Officers" of the United States in the "Courts of Law." Under this clause, Congress has passed two statutes, Federal Rule of Criminal Procedure 42(b) ${ }^{155}$ and the Ethics in Government Act, ${ }^{156}$ that authorize the courts to appoint prosecutors without the consent of the executive branch in certain situations. ${ }^{157}$ In both cases, the court's appointınent actually initiates the criminal prosecution. ${ }^{158}$

595-97 (describing cases in which the courts have reviewed agency inaction as "reject[ing] the premise that a federal prosecuting official can rely on purportedly complete discretion to justify the disregard of a statutory mandate").

152. Buckley v. Valeo, 424 U.S. 1, 121 (1976) (per curiam).

153. Nixon v. Administrator of General Services, 433 U.S. 425,442 (1977).

154. U.S. ConsT. art. II, § 2, cl. 2.

155. FED. R. CRIM. P. 42(b). Although Rule 42(b) does not explicitly authorize judicial appointment of prosecutors, courts have interpreted the Rule's notice requirement to implicitly grant such authority. See supra note 57 and accompanying text.

156. 28 U.S.C. $\$ \S 591-598$ (1982).

157. Besides these two statutes, current law and practice already afford the judiciary a significant role throughout the charging process. First, a magistrate in a preliminary hearing determines whether the United States Attorney can bring a prosecution. Rules 5 and 5.1 of the Federal Rules of Criminal Procedure require a magistrate to make a prelimmary examination of the evidence against a criminal defendant and to disiniss the complaint if it does not show probable cause that defendant committed the offense. FED. R. CRIM. P. 5, 5.1.

Furthermore, once the defendant has been charged, the United States Attorney must obtain the court's consent before plea bargaining. Rule 11 of the Federal Rules of Criminal Procedure provides that a court may refuse to accept a plea of guilty even though the prosecutor has agreed to the reduced charge. FED. R. CRIM. P. 11; see United States v. Ammidown, 497 F.2d 615, 622 (D.C. Cir. 1973) ("The judge may withhold approval [of the guilty plea] if he finds that the prosecutor has failed to give consideration to factors that must be given consideration in the public interest.").

Finally, the court can overrule the United States Attorney's decision to dismiss a charge. FED. R. CRIM. P. 48(a). The district court can deny the government's motion to dismiss where it appears that the United States Attorney is motivated by considerations clearly contrary to manifest public interest. See Rinaldi v. United States, 434 U.S. 22, 30 (1977); United States v. Hamm, 659 F.2d 624, 628-30 (5th Cir. 1981).

158. Another statute permits the federal courts to appoint a temporary United States Attorney 
In recent challenges to these two statutes, ${ }^{159}$ the Supreme Court purported to take a strict constructionist approach, analyzing whether the challenged reallocation of prosecutorial discretion fit within the allocation of powers as specified in the text of the Constitution. ${ }^{160}$ Since the Constitution provides only general outhnes of this allocation, however, the analysis devolved predictably into consideration of two primary factors: (1) the degree to which the allocation of power to the judiciary intrudes on the executive's traditional prosecutorial functions and discretion, and (2) the importance of the value sought to be achieved by Congress's reallocation of authority. ${ }^{161}$ In both cases, the Court found the intrusion on executive prosecutorial discretion justified by the purpose of the statute.

In Young v. United States ex rel. Vuitton et Fils S.A. ${ }^{162}$ the United States Supreme Court heard a challenge to Federal Rule of Criminal Procedure 42(b), which authorizes courts to initiate prosecution for criminal

when a vacancy arises. 28 U.S.C. $\$ 546$ (Supp. 1987). This appointment, however, does not initiate a prosecution; it merely fills the vacancy until the executive branch appoints a permanent United States Attorney. See United States v. Solomon, 216 F. Supp. 835, 840-43 (S.D.N.Y. 1963) (upholding this statutc against a separation of powers challenge).

159. Morrison v. Olson, No. 87-1279 (U.S. June 29, 1988); Young v. United States ex rel. Vuitton et Fils S.A., 107 S. Ct. 2124 (1987).

160. See, eg., Morrison, No. 87-1279, slip. op. at 16-17 (examining accounts of debates in the Constitutional Convention to interpret the Appointments Clause).

161. Two recent Suprene Court cases have explicitly defined this test as the appropriate means of analyzing congressional legislation under the separation of powers doctrine. In Nixon $v$. Administrator of General Services, 433 U.S. 425 (1977), the Court explained that:

[I]n determining whether the Act disrupts the proper balance between the coordinate branches, the proper inquiry focuses on the exteut to which it prevents the Executive Branch from acconiphishing its constitutionally assigned functions. Only where the potential for disruption is present nust we then determine whether that impact is justified by an overriding need to promote objectives within the constitutional authority of Congress.

Id. at 443 (citations omitted). See also United States v. Nixon, 418 U.S. 683, 711-13 (1974) (stating that a President's generalized interest in confidentiality, while constitutionally based, can be overcome by a specific need for evidence in a criminal trial).

Effective goverimient demands this flexible approach. In fact, the existence of regulatory agencies is an example of the inalleabihty of the separation of powers. A strict interpretation of the text of the Constitution would deny Congress the power to create these agencies, since they perform functions that were constitutionally granted to each of the three separate branches of governmentprounulgation of regulations, prosecution of violators, and adjudication of enforcement actions. In Commodity Futures Trading Comm'n v. Schor, 106 S. Ct. 3245 (1986), for example, the Court upheld the CFTC's authority to entertain'state law counterclaims in reparations proceedings, rejecting the argument that article III of the Constitution vested the authority to hear such claims exclnsively in the federal courts. The Court decided that the agency's authority constituted a "de minimus" intrusion on the authority of the judicial branch, and that traditional separation of powers did not justify defeating the legislative purpose of furnishing an efficient inethod for resolving such claims. Id. at 3260. Explaining its flexible approach to this separation of powers issue, the Court concluded that "bright line rules cannot effectively be employed to yield broad principles applicable in all Article III niquiries." Id. at 3261.

162. 107 S. Ct. 2124 (1987). 
contempt and to appoint attorneys to prosecute the charge. ${ }^{163}$ The Court employed the two-pronged separation of powers analysis to uphold the judicial appointment power. The Court determined that because this procedure would be used "only as a last resort," it did not impermissibly intrude on executive charging discretion. ${ }^{164}$ It also emphasized the judiciary's need to protect its authority in the event that the United States Attorney fails to prosecute contempt violations. ${ }^{165}$

In Morrison v. Olson, ${ }^{166}$ the Supreme Court reviewed the Ethics in Government Act, ${ }^{167}$ which provides for the judicial appointment of an independent prosecutor to investigate and prosecute alleged criminal activity by enumerated high government officials. The D.C. Circuit Court of Appeals had decided that the statute violates the constitutional separation of powers because it infringes the executive's power to appoint prosecuting attorneys under the appointments clause ${ }^{168}$ and its discretionary authority to prosecute criminal actions under article II. ${ }^{169}$ The Supreme Court reversed the lower court decision, explaining that the statutory reallocation of authority conforins to the constitutional structure of federal government. ${ }^{170}$ Moreover, it justified the infringement of executive prerogatives with the statutory purpose of ensuring independent prosecution of corruption in the executive branch. ${ }^{171}$

163. See supra notes 57-59 and accompanying text.

164. Young, $107 \mathrm{~S}$. Ct. at 2134.

165. Id. ("If the Judiciary were completely dependent on the Executive Branch to redress direct affronts to its authority, it would be powerless to protect itself if that branch declined prosecution.")

166. 87-1279 (U.S. June 29, 1988).

167. 28 U.S.C. $\$ \S 591-598$ (1982).

168. U.S. CoNST. art. II, $\S 2$, cl. 2. The court found that the judicial appointment procedure violated the separation of powers, and was not warranted by the appointments clause of the Constitution. In re Sealed Case, 838 F.2d 476, 494-96 (D.C. Cir. 1988). The appointments clause grants the executive the power to appoint "Officers of the Urited States," but permits Congress to vest the authority to appoint "inferior Officers" in the judiciary. U.S. CoNST. art. II, § 2, cl. 2. The court determined that the independent prosecutor was a "principal officer," and not an inferior officer appointable by the courts, primarily because her authority "is so broad as to compel the conclusion that she is a primcipal officer." In re Sealed Case, 838 F.2d at 486 . Moreover, the independent counsel is not hierarchically "inferior" to any superior official. "The Attorney General ... cannot be thought of as the imdependent counsel's constitutional superior. Under the statute, the Attorney General has the effective power neither to appoint her, to define, circumscribe, or supervise her duties, nor to remove her or terminate her office." Id. at 485 . Consequently, the court found that the appointment power violated the separation of powers.

169. U.S. CONST. art. II, § 3 .

170. Morrison, No. 87-1279 (U.S. June 29, 1988). The Court actually made threc related holdings in its determination that this procedure satisfied the federal separation of powers. It first found that the judicial appointment power does not violate the appointments clause. Id. at 11-18. The Court further held this power does not breach the article III himitations on judicial authority. Id. at 18-26. Finally, it deterimined that the judicial power to initiate prosecution under the Act does not impermissibly interfere with the functions of the executive branch. Id. at 26-37.

171. Id. at 18, 34 (jnstifying the judicial appointment power and the limitation on the executive's power to remove the independent counsel, respectively, with the congressional concern in maintaining the prosecutor's independence from the executive branch). 


\section{Analysis}

The Court's acceptance of these two statutory schemes indicates that this proposed procedure similarly accords with the federal separation of powers. In fact, the traditional two-prong analysis clearly demonstrates the constitutionality of this contemplated reallocation of prosecutorial authority. First, an evaluation of this proposal, in comparison with the statutory procedures in Young and Morrison, confirms that it does not impermissibly intrude on executive prerogatives. Second, an analysis of the purpose behind the proposal reveals that any resulting mtrusion is justified by the need to protect crime victims from further injury.

\section{a. Intrusiveness}

Under the proposed procedure, the executive would no longer wield absolute power over the prosecutorial decision. ${ }^{172}$ If a criminal charge is warranted by the facts and the petitioning victim demonstrates the requisite standing, ${ }^{173}$ a court may imitiate a prosecution regardless of the executive's refusal to prosecute. The executive can prevent the prosecution only if it demonstrates "good cause" for vacating the charge. ${ }^{174}$

This intrusion, though significant, does not constitute an unacceptable inroad into executive decisionmaking. ${ }^{175}$ The proposed procedure sufficiently protects traditional authority. In fact, this scheme is even less imtrusive than the independent prosecutor procedure that was recently upheld in Morrison. While the Ethics in Government Act explicitly denies the executive the power to prosecute crimes that fall under the Act, ${ }^{176}$ this proposal places no restrictions on the executive's traditional

172. The executive traditionally reserves absolute power to decline to prosecute a given criminal suspect. This negative prosecutorial discretion is an important element in executivc policymaking, simce a negative charging decision may reflect a reasoned policy choice to leave certain criminal laws unenforced. See F. MILLER, supra note 68, at 162 ("[I]t lies with the District Attorney to determine whether acts which may fall within the literal letter of the law should as a matter of public policy not be prosecuted." (citing Hassan v. Magistrate's Court, 20 Misc. 2d 509, 514, 191 N.Y.S.2d 238, 243 (Sup. Ct. 1959))).

173. See supra notes $\mathbf{8 3 - 8 8}$ and accompanying text.

174. See supra note 90 and accompanying text.

175. Note that, for practical reasons, this proposal has no effect on the bulk of executive prosecutorial decisionmaking. Relatively few of the executive's negative charging decisions will be overturned. Judges will not approve victim petitions indiscriminately. They must first review these petitions with a formal presumption in favor of the executive's decision not to prosecute, and approve them only if the victim has satisfied the requisite showing of probable cause and futurc violations. See supra text accompanying notes 83-88.

176. Morrison, no. $87-1279$, slip. op. at 4 ("[W] independent counsel under the Act, the Attorney General and the Justice Department arc required to suspend all investigations and proceedings regarding the matter."); see Dellums v. Smith, 577 F. Supp. 1449, 1451 (N.D. Cal. 1984) (citing legislative history explaining that the purpose of the Act is to ensure that serious allegations against high-level officials will be pursued by independent counsel). 
prosecutorial powers.

First, it does not impair the executive's authority to appoint "Officers of the United States" under the appointments clause. ${ }^{177}$ The executive retains the authority to staff any case it decides to prosecute, and executive personnel can step in for an appointed prosecutor in any court-imitiated prosecution.

Second, the proposal does not encroach on the executive's authority to "take Care that the Laws be faithfully executed." 178 It purposely restricts the judiciary's exercise of this appointinent authority so as to preserve executive discretion. It takes no cases out of the executive's hands; the United States Attorney's Office still retains the first opportunity to charge in all cases. As in the Rule 42 (b) procedure, the judge initiates a prosecution ouly after that office refuses to charge, ${ }^{179}$ and the United States Attorney has the right to participate in or take over the prosecution at any point in the proceedings. Moreover, the executive retains its authority over enforcement policy because it has the power to prevent the prosecution when it can demonstrate that the charge is contrary to public interests. ${ }^{180}$

177. The Supreme Court was willing to accept the judicial appointment power under the Ethics in Government Act, in part, because, "in light of judicial experience with prosecutors in criminal cases, it could be said that courts are especially well qualified to appoint prosecutors." Morrison, No. 87-1279, slip. op. at 17 n.13.

178. U.S. CONST. art. II, § 3.

179. The Solicitor General of the Uinited States, representing the executive brancli as Amicus Curiae in Young v. Uinted States ex rel. Vuitton et Fils S.A., 107 S. Ct. 2124 (1987), conceded that this safeguard was sufficient to protect executive authority. The separation of powers would be protected, he said, so long as the United States Attorney first liad the opportunity to consider the criminal contenpt and declined prosecution before tlie court exercised its appointinent power under Rule 42(b). Brief for the United States as Amicus Curiae at 11-19, Young (Nos. 85-1329 and 856207).

180. See supro notes $89-91$ and accompanying text.

This proposal might conceivably impinge on executive prerogatives by undermining the discretion of the regulatory agencies. Regulatory legislation frequently vests the authority to apply and enforce a body of federal statutes in a regulatory agency or departinent. See, eg., Occupational Safety and Health Act of 1970, 29 U.S.C. $\$ 659$ (1982) (authorizmg the Secretary of Labor to enforce the provisions of the Act). These statutes typically authorize agencies to exercise a range of enforccinent measures, such as civil proceedings, agency enforccment actions, and informal negotiations.

When they discover a violation, agencies must have the discretion to decide on the appropriate ineans of enforccment. See, e.g., Hawkins, Bargain and Bluff: Compliance Strategy and Deterrence in the Enforcement of Regulation, 5 L. \& PoL'Y Q. 35 (1983) (describing low agencies sonetimes overlook lesser violations in exchange for a pronise that the offender will mect broader guidelines). If this proposal were to allow victims of regulatory violations to iusist on criminal prosecution, it would undermine the agency's authority and capacity to enforce its legislative mandate by alternative neans.

The procedure proposed here does not significantly affect this regulatory discretion. In the first place, most agency decisionmaking is not subject to this proposal since the vast majority of administrative enforcement actions involve civil, rather than criminal, penalties. Regulatory statutes typically authorize the head of the relevant agency or department to impose civil penalties for violations of the Code. See, e.g., Occupational Safety and Health Act, 29 U.S.C. $\S 659$ (1982) 


\section{The Value Justifying Reallocation of Prosecutorial Authority}

Even though this proposal infringes executive power to a degree, that infringement is justified by the purpose of the proposal; to extend protection to crime victims who are vulnerable to further victimization. Although the American criminal justice system is designed to prevent crime through deterrence, ${ }^{181}$ the systein fails to fulfill its mission in one notable situation. The crime victim who faces imminent danger of continued harm by the same offender is vulnerable to revictimization when the state refuses to prosecute the offender and effective civil and equitable remedies are unavailable.

The government's failure to prosecute in this situation compromises the very validity of that government. When the executive fails to protect a crime victim from revictimization, it calls into question the legitimacy of its exclusive prosecutorial powers. ${ }^{182}$ Unless another branch of government provides the necessary protection to these victims, the social contract that bimds citizen to state is jeopardized. The ultimate result is victim frustration and alienation, and even vigilantism, as victims decide to protect their interests with extra-legal measures. ${ }^{183}$ Under these cir-

(Secretary of Labor can propose civil penalties for violations of the Act, which the alleged violator can contest). Although the distinction between "civil" and "criminal" penalties is not always clear, monetary penalties prescribed in regulatory statutes have consistently been considered civil. See, e.g., Helvering v. Mitchell, 303 U.S. 391 (1938) (assessment by the Internal Revenue Service of a fine of $50 \%$ of a taxpayer's deficiency is a "civil" sanction); Mohawk Excavating v. Occupational Safety and Health Review Comm'n, 549 F.2d 859 (2d Cir. 1977) (imposition of $\$ 1000$ fine for OSHA violation is not a criminal sanction). Since this proposal applies only to criminal actions, it has no effeet on these civil enforcement actions.

The proposal may affect agency discretion in one narrow situation, however: wherc an agency discovers a violation of a regulatory statute that provides for criminal penalties. See, e.g., Occupational Safety and Health Act, 29 U.S.C. $\$ 666$ (1982) (subjecting employers to criminal penalties for willful safety violations resulting in the death of an employee). When an agency discovers a criminal violation, it can respond with a civil action or refer the case to the United States Attorney for prosecution. See generally Rabin, Agency Criminal Referrals in the Federal System, in Perspectives on the Administrative Process 183 (R. Rabin ed. 1979).

The agency's discretion to respond to this criminal violation with civil rather than criminal action is protected under the proposal by the executive's power to appeal the court's appointment of a prosecutor. If a court decides to initiate prosecution for a criminal violation of a regulatory statute, it must first notify the agency responsible for enforcing that act. The head of that agency can then veto the court's action by the appeal power upon showing good cause. The agency's use of noncriminal enforcement measures against a particular violator, for example, may constitute good cause to justify termination of a court-initiated prosecution of that violator.

181. See supra notes 7-8 and accompanying text.

182. See supra notes $14-15$ and accompanying text.

183. When victims are left vulnerable to continued criminal injnry by the prosecutor's refusal to charge, they are liable to take the law into their own hands and strike the criminal before he strikes them again. "When people begin to believe that organized society is unwilling or unable to impose upon criminal offenders the punishment they 'deserve,' then there are sown the seeds of anarchy-of self-help, vigilante justice, and lynch law." Furman v. Georgia, 408 U.S. 238, 308 (1972) (Stewart, J., concurring); see also Aynes, supra note 12, at 70 ("[T]he government's breach of the social contract ... releases the people from any moral obligation to adhere to its laws or processes."). By 
cumstances, this proposal is justified in empowering the judiciary to protect vulnerable victims whom the executive has disregarded in its exercise of prosecutorial discretion.

\section{CONCLUSION}

Under the prevailing system of prosecutorial discretion, a crime victim has no voice in the decision to charge an alleged crimmal offender. In most cases, tlins public monopoly of prosecutorial discretion is justified. The policy objectives of the crimimal justice system-retribution, rehabilitation, and deterrence-are public interests that should only be pursued by the public's representative. In situations where the crime victim must rely on criminal prosecution to deter further victimization by the offender, however, the victim has a personal interest in the prosecution: for this victim, criminal prosecution is the sole means of protection from future injury.

The government has a correlative responsibility to protect that victim from subsequent violation where no civil alternative exists. If the government knowingly refuses to protect the victim through prosecution, it breaches its duty under social contract theory and undermines the legitimacy of its monopoly control of criminal law enforcement. At this point, the victim is justified in seeking to override the prosecutor's negative charging decision through court-initiated prosecution.

The specific procedure described above is but one means of achieving the necessary protection of crime victims within the criminal justice system. This Comment describes its operation, not to suggest that it is the only means, but to demonstrate that a legislature can remedy the shortcomings of the prevailing situation within the constitutional limits as defined under due process and separation of powers doctrines. By adopting a court appointment procedure similar to this proposal, the federal and state legislatures can produce a prosecutorial system that more fully protects the cognizable interests of crime victims.

Kenneth L. Wainstein*

providing a legal recourse to the prosecutor's negative charging decision, this proposal allows these victims to protect themselves without resorting to vigilantism or other undesirable forms of self-help. * B.A. 1984, University of Virginia; third-year student, Boalt Hall School of Law, University of California, Berkeley.

The author would like to thank Professor John P. Dwyer, without whose support, both moral and scholarly, this Comment would not have becn written. 
